ECONOMIC GROWTH CENTER

YALE UNIVERSITY

P.O. Box 208629

New Haven, CT 06520-8269

http://www.econ.yale.edu/ egcenter/

CENTER DISCUSSION PAPER NO. 928

\title{
Institutions and Development: A View from Below
}

\author{
Rohini Pande \\ Yale University \\ and \\ Christopher Udry \\ Yale University
}

November 2005

Notes: Center Discussion Papers are preliminary materials circulated to stimulate discussions and critical comments.

We have greatly benefitted from discussions with Daron Acemoglu, Tim Besley and James Robinson. We are grateful to our discussant Orazio Attanasio for comments. Finally, we thank James Fenske and Pinar Keskin for fantastic research assistance.

This paper can be downloaded without charge from the Social Science Research Network electronic library at: $\underline{\text { http://ssrn.com/abstract }=864044}$

An index to papers in the Economic Growth Center Discussion Paper Series is located at: http://www.econ.yale.edu/ egcenter/research.htm 


\title{
Institutions and Development: A View from Below \\ Rohini Pande and Christopher Udry
}

\begin{abstract}
In this paper we argue the case for greater exploitation of synergies between research on specific institutions based on micro-data and the big questions posed by the institutions and growth literature. To date, the macroeconomic literature on institutions and growth has largely relied on cross-country regression evidence. This has provided compelling evidence for a causal link between a cluster of 'good' institutions and more rapid long run growth. However, an inability to disentangle the effects of specific institutional channels on growth or to understand the impact of institutional change on growth will limit further progress using a cross-country empirical strategy. We suggest two research programs based on micro-data that have significant potential. The first uses policy-induced variation in specific institutions within countries to understand how these institutions influence economic activity. The second exploits the fact that the incentives provided by a given institutional context often vary with individuals' economic and political status. This can help us better understand how institutional change arises in response to changing economic and demographic pressures.
\end{abstract}

JEL codes: O11, O12, O17, P51

Keywords: Institutions, Growth, Cross-Country Regressions 


\title{
Institutions and Development: A View from Below
}

\author{
Rohini Pande and Christopher Udry \\ Yale University*
}

November 18, 2005

\begin{abstract}
In this paper we argue the case for greater exploitation of synergies between research on specific institutions based on micro-data and the big questions posed by the institutions and growth literature. To date, the macroeconomic literature on institutions and growth has largely relied on cross-country regression evidence. This has provided compelling evidence for a causal link between a cluster of 'good' institutions and more rapid long run growth. However, an inability to disentangle the effects of specific institutional channels on growth or to understand the impact of institutional change on growth will limit further progress using a cross-country empirical strategy. We suggest two research programs based on micro-data that have significant potential. The first uses policy-induced variation in specific institutions within countries to understand how these institutions influence economic activity. The second exploits the fact that the incentives provided by a given institutional context often vary with individuals' economic and political status. This can help us better understand how institutional change arises in response to changing economic and demographic pressures.
\end{abstract}

\section{Introduction}

Recent years have seen a remarkable and exciting revival of interest in the empirical analysis of how a broad set of institutions affects growth. The focus of the recent outpouring of research

\footnotetext{
${ }^{*}$ We have greatly benefitted from discussions with Daron Acemoglu, Tim Besley and James Robinson. We are grateful to our discussant Orazio Attanasio for comments. Finally, we thank James Fenske and Pinar Keskin for fantastic research assistance.
} 
is on exploiting cross-country variation in 'institutional quality' to identify whether a causal effect runs from institutions to growth. These papers conclude that institutional quality is a significant determinant of a country's growth performance.

These findings are of fundamental importance for development economists and policy practitioners in that they suggest that institutional quality may cause poor countries and people to stay poor. However, the economic interpretation and policy implications of these findings depends on understanding the specific channels through which institutions affect growth, and the reasons for institutional change or the lack thereof. However, for reasons discussed below, we argue that the coarseness of cross-country data limits its usefulness for such research. Instead, we suggest that a more fruitful research agenda is to exploit the synergies between research based on micro-data and the questions posed by the institutions and growth literature.

North (1981) defines an economic institution as "a set of rules, compliance procedures and moral and ethical behavioral norms designed to constrain the behavior of individuals in the interests of maximizing the wealth or utility of principals." (p.201-202). We adopt his definition of institutions as sets of rules, procedures or norms that constrain behavior but disagree with the notion of agency embodied in this definition. Institutions need not be 'designed', and even if they are, their actual operation may be quite different than intended. For this reason, we emphasize a research agenda on institutions which pays attention to de facto rather than de jure institutions and one that pays attention to how changes in resource endowments can cause individuals to change their economic behavior within a given institutional context and potentially cause the institution itself to change in the longer run. Such a focus is particularly relevant when thinking about institutions in low income countries - since development, by definition, is about change.

In section 2 we summarize the main insights from the cross-country literature on institutions and growth. This literature has successfully focussed attention on the complex interactions between economic growth and institutional development. It has uncovered important correlations across countries between growth and the nature and quality of a core set of economic, political and social institutions. This literature has also been careful in noting, and accounting for, the fact that institutions and economic growth jointly cause each other. A positive correlation between 'good' institutions and growth may reflect reverse causation; faster growing countries 
may have 'better' institutions because they can afford them. Faced with the statistical challenge of isolating causal pathways, authors have been extraordinarily inventive in identifying features of countries that are plausibly exogenous to the growth process, but that might influence the character of institutional development and thus might serve as instrumental variables. However, we argue that this literature has served its purpose and is essentially complete. The number of variables available as instrumental variables is limited, and their coarseness prevents close analysis of particular causal mechanisms from institutions to growth. Further, the fact that instruments tend to be derived from persistent features of a country's institutional environment such as its colonial past limits their usefulness for studying institutional change.

This suggests that the research agenda identified by the institutions and growth literature is best furthered by the analysis of much more micro-data than has typically been the norm in this literature. In section 3 we describe how policy-induced variation in institutional form within a country can be exploited to examine how specific institutions influence economic outcomes. An important advantage of such studies is that information about how such change was implemented across regions in the country and/or differences in the regional incidence of the policy can very often be exploited to obtain instruments for specific institutions.

Finally, in section 4 we discuss a different but complimentary research focus - close examinations of the economic choices of individuals in a specific institutional context. A given institutional setting can provide a rich variety of incentives to different individuals, depending upon their economic and political standing. Further, one can potentially also examine institutional change in response to changing factor endowments. We illustrate this research agenda with an example from Ghana, in which we analyze the effects of a complex land tenure system on investment incentives, and provide some evidence regarding the historical evolution of that institution and some indications of how changes in economic environment may cause individuals to take actions that have the potential to transform the institutional environment.

\section{Cross-Country Analysis}

In this section we summarize the important recent contributions to the empirical institutions and growth literature, and then discuss reasons why we believe this literature to be essentially 
complete. In Table 1 we list five widely cited papers in this literature, which we term 'Core Papers'. These are the papers which were the first to use (and often develop) influential institutional quality measures or instrumental variables to address the endogeneity of institutional measures. We then describe 'papers citing core papers'. These are articles which cite at least one core paper, and are published or forthcoming (that we could identify) in the following journals: American Economic Review, Econometrica, Journal of Development Economics, Journal of Economic Growth, Quarterly Journal of Economics, Journal of Political Economy and Review of Economic Studies. We restrict attention to papers with at least one cross-country regression which consider a measure of the country's growth performance (or well-being of the population) as the outcome variable of interest and include a measure of institutional quality as an explanatory variable. ${ }^{1}$

For each paper, Table 1 describes the outcome variable of interest, the institutional measure, the instrumental variables used and the paper's main finding. Typically, we report the estimates for the most basic specification in the paper.

\subsection{Observations}

The resurgence of the cross-country literature on institutions and growth is clearly linked to two factors. The first is the availability of comparable measures of institutional quality for a large set of countries, and second there is the use of instrumental variable techniques to deal with the endogeneity of institutions. This is a rich and active literature with much debate about the suitability of empirical strategies adopted by the different papers, the validity of their identification assumptions and the relative magnitudes of the effects of different kinds of institutions on growth outcomes. From Table 1 we pull together some observations about this literature.

\section{A. Institutions Matter}

Almost without exception, the papers listed in Table 1 find a robust positive correlation between growth outcomes and an array of measures of institutional quality. Looking across countries,

\footnotetext{
${ }^{1}$ Our focus implies we exclude an important companion literature which examines how institutional quality affects policy outcomes, such as the size of government.
} 
the literature argues that improvements in the quality of contracting institutions, better law enforcement, increased protection of private property rights, improvements in central government bureaucracy, improved operation of formal sector financial markets, increased levels of democracy, and higher levels of trust are all correlated with higher economic growth.

\section{B. Comparable institution measures are coarse and urban-based}

The main focus in this literature has been on using aggregate measures of institutional quality, and one of the strengths of this literature is the broad range of such measures that it examines. Many of the papers rely on indicators generated by organizations whose primary purpose is to provide assessments of the various forms of political risk or of the contractual environment in countries around the world. These sources (for example, Political Risk Services, Business Environmental Risk Intelligence, or the Economist Intelligence Unit) have the important advantage of being expressly designed to be comparable across countries. For example, a 'protection against expropriation' score of 7 from Political Risk Services is supposed to mean the same thing in any country of the world. Most of these measures relate to institutional quality as faced by businesses and individuals in the more formal urban sector. It is also the case that this literature, almost by definition, has to treat 'institutions' coarsely. The fundamental problem is that the dimension of the vector of institutions that we believe influences growth is extremely large. Because some dimensions are unobserved (by nature, or because of data problems) and because the number of countries is small, regressions never include this whole vector of institutions on the right hand side.

\section{Instruments are rare}

There is widespread recognition of the fact that institutional form may be determined by economic performance. In Table 1 we see that a very small number of variables have been called upon to identify the causal effects of the wide range of institutions examined in the literature. The key instrumental variables have been based on geography (distance from equator and predicted trade share, oil exporter) and colonial and pre-ccolonial history (settler mortality, legal origin, ethnic and linguistic composition, precolonial population density, state antiquity). The paucity of plausible instruments arises from the fact that there are few variables that are im- 
portant determinants of the current form of a particular economic institution but affect growth only through that institution.

Another striking feature is that the same variable is often used in different studies as an instrument for different indices of institutions, and interpreted in varying ways. Consider settler mortality. It is used to instrument for: (i) protection against expropriation risk; (ii) executive constraints; (iii) measures of financial depth such as private credit; (iv) a rule of law index; and (v) the overall index of institutional quality. ${ }^{2}$

\section{Persistent Institutional Effects}

The instruments that dominate the literature are based on geography and colonial and precolonial history. These variables exploit long term persistent institutional features of a country. The IV strategy purges the estimates of the effect of any institutions that change along the path of development, because these are clearly endogenous to the growth process. This, however, implies that the IV strategy by design is not able to identify the consequences of institutional change for growth.

\section{E. IV estimates typically exceed OLS estimates}

IV estimates of the institutions growth relationship are always significantly larger than the OLS estimates. Given that endogeneity concerns would suggest an upward bias in the OLS estimate, a common interpretation is attenuation bias in the OLS due to measurement error.

\subsection{The Limits of Cross-Country Analysis}

Based on these observations we now suggest that the general approach of this literature may not be compatible with further progress on exploring the channels through which institutions affect economic development, or on understanding how institutional change can affect growth. Some of our arguments, especially the problems with using measures based on a country's colonial

\footnotetext{
${ }^{2}$ Another remarkable fact is that almost all the variables that serve as instruments were introduced in one of the five core papers as instruments or institutions. Only state antiquity, the oil exporter dummy and the proportion of postsecondary law students in 1963 have been introduced in the 16 papers that follow. This is a further indication of the difficulty of finding suitable instruments for endogenous institutions.
} 
past to instrument for specific institutions, have already received attention in the institutions and growth literature; for a very complimentary analysis see Acemoglu (2005).

\section{A. Coarseness of institutional measures and instruments}

The cross country literature has largely relied on broad indices of institutional quality. A first concern is that the construction of these indices requires subjective valuations of what belongs in the index. Typically, the information that underlies the indices is not fully public, and reflects the subjective judgements of analysts at the risk assessment organization. For example Political Risk Services (PRS) constructs the widely-used ICRG measures. The ICRG provides a number of indicators, most of which rely on a combination of objective information about the country and subjective assessments of PRS analysts and their research team (moreover, different papers combine these indicators in different ways). PRS reported to us that to construct the commonly-used 'protection against expropriation risk' index,

"we 'infer' the risk involved from the degree of accountability of the government, the freedom of the judiciary, the level of application of the rule of law, and the level of apparent corruption" (personal communication 15 July 2005).

We have no reason to doubt the competence or judgement of those who construct the indicators, and indeed, the fact that investors are willing to pay for this information shows that the indicators are associated with something that investors care about. However, the opacity of construction of these indicators limits open debate about these judgements. Other measures of institutional development used in these papers are subject (to greater or lesser degrees) to the same difficulty. ${ }^{3}$

A second concern relates to arbitrary choice of weights to combine the underlying subindices (the most common index is an unweighted average of the sub-indices - the notes to Table 1 describe the construction of the different indices of institutional quality). This makes

\footnotetext{
${ }^{3}$ These include the BERI index, the Economist Intelligence Unit's indices of bureaucratic efficiency and institutional efficiency, the Freedom House democracy index, and (to a much lesser degree) executive constraints and the index of democracy (from Polity III and Polity IV). Obviously, some measures of institutional development are not subject to this concern. For example, the index of trust (Knack and Keefer 1997) is based on survey responses to a specific question; readers can make their own judgement regarding the suitability of the measure.
} 
interpreting the estimated impact of institutional quality, and relating this estimated impact to the true effect of the underlying institutions, problematic. To see this more clearly, consider the basic model used in this literature

$$
y_{i}=\beta_{0}+\beta x_{i}+v_{i}
$$

where $y_{i}$ is growth and $x_{i}$ an index of institutional development. Of course there are multiple control variables but we exclude these for clarity (though their choice and treatment is essential). In most cases, the literature recognizes that $x_{i}$ is endogenous and relies on a first stage

$$
x_{i}=\gamma_{0}+\gamma z_{i}+\xi_{i}
$$

for some instrument $z_{i}$. Again, this might include various control variables, and sometimes it is placed into a panel data context.

Suppose, however, that the correct model is

$$
y_{i}=\beta_{0}+\beta_{1} x_{1 i}+\beta_{2} x_{2 i}+\varepsilon_{i}
$$

where $x_{1}$ and $x_{2}$ are 2 different institutions that matter. Instead of estimating their separate effect, papers in the cross country literature use an aggregate index of institutional quality, such as the ICRG index of overall institutional development, defined as

$$
x_{i}=\alpha_{1} x_{1 i}+\alpha_{2} x_{2 i}
$$

with the weight $\alpha_{k}$ defined by a Political Risk Services analyst. The actual equation estimated is (1), which is equivalent to imposing the restriction that $\alpha_{1} \beta_{1}=\alpha_{2} \beta_{2}$. If this restriction is incorrect, what are we actually estimating?

The instrument $z$ in $(2)$ is related to the underlying $x_{k}$ by

$$
\begin{aligned}
& x_{1 i}=\gamma_{10}+\gamma_{1} z_{i}+\xi_{1 i} \\
& x_{2 i}=\gamma_{20}+\gamma_{2} z_{i}+\xi_{2 i}
\end{aligned}
$$

So we have

$$
x_{i}=\alpha_{1} \gamma_{10}+\alpha_{2} \gamma_{20}+\left[\alpha_{1} \gamma_{1}+\alpha_{2} \gamma_{2}\right] z_{i}+\alpha_{1} \xi_{1 i}+\alpha_{2} \xi_{2 i} .
$$


The probability limit of the IV estimator is

$$
p \lim \hat{\beta}_{I V}=\frac{\beta_{1} \gamma_{1}+\beta_{2} \gamma_{2}}{\alpha_{1} \gamma_{1}+\alpha_{2} \gamma_{2}} .
$$

Three key problems are readily apparent.

First, our estimate of the effect of institutions on growth depends on the arbitrary weights $\alpha_{k}$ used to weight the various components of the index of institutional development. Therefore, $\hat{\beta}_{I V}$ cannot estimate a structural feature of the underlying economies.

Second, the coarseness of our measures of institutions implies that we estimate a 'composite' effect of multiple institutions on growth. $\hat{\beta}_{I V}$ depends on the underlying structural relationship between specific institutions and growth, but not in a simple fashion. While institutional measures are correlated, it is clear that the economic interpretation of, say, 'executive constraints' and 'private credit' differ. We would, therefore, want to distinguish between their effects on growth. However, our measures of institutions do not permit rich disaggregation. ${ }^{4}$

Third, even when more disaggregated measures of institutions are available, there is a clear paucity of plausible instruments that can serve to identify the causal effect of institutions on growth. There are few variables that are important determinants of the current form of a particular economic institution and that do not have effects on growth other than through that institution. Hence, important as these variables might be as determinants of a particular institution, an IV strategy can rarely isolate the causal pathway. Since these broad underlying features of an economy (e.g., settler mortality, colonial history, position on the earth's sphere) have myriad effects on the institutions and economic organization of a society they are not valid instruments for any particular institution. Indeed, there is a real danger that the instrument may have different relationships with the underlying institutions; that is, that $\gamma_{k}$ might have opposite signs. In this case, the estimated $\hat{\beta}_{I V}$ can fall outside the range of the underlying $\beta_{k}$. One

\footnotetext{
${ }^{4}$ The composite nature of the estimated $\hat{\beta}$ is not a consequence of the IV strategy. If $v_{i}$ is uncorrelated with $x_{i}$, then the probability limit of the OLS estimator of (1) is

$$
p \lim \hat{\beta}=\frac{\alpha_{1} \beta_{1} \sigma_{x_{1}}^{2}+\alpha_{2} \beta_{2} \sigma_{x_{2}}^{2}+\left(\alpha_{2} \beta_{1}+\alpha_{1} \beta_{2}\right) \sigma_{x_{1} x_{2}}^{2}}{\alpha_{1}^{2} \sigma_{x_{1}}^{2}+\alpha_{2}^{2} \sigma_{x_{2}}^{2}+2 \alpha_{1} \alpha_{2} \sigma_{x_{1} x_{2}}^{2}} .
$$

While this parameter can give a broad-brush picture of the relationship between institutions and growth, it will be hard to say anything about the relative importance of the components of the composite indicators. If these components are negatively correlated, then the estimated $\hat{\beta}$ may even fall outside the range of $\left[\beta_{1}, \beta_{2}\right]$
} 
context in which this might happen is where there is a trade-off between the institutions, where improving one institution might be at the cost of worsening another. This should arise most commonly when there are negotiation or cost trade-offs in the construction and development of institutions.

\section{B. Omitted Variables}

We noted earlier that, in every case, an IV approach strengthens the positive effect of institutional quality on growth performance. There is no doubt that the measures of institutions are afflicted by classical measurement error. However, because of the unquestionable ubiquity of omitted unobserved variables, it is worth considering their effect on the IV estimates as well.

Consider the simplest form of omitted variables bias. Despite the use of very broad indices of institutions, other institutions are unmeasured and left out of the estimated equation. That is, (??) is constructed using $\alpha_{1}=1$ and $\alpha_{2}=0$. The probability limit of $\hat{\beta}_{I V}$ is now

$$
\operatorname{plim} \hat{\beta}_{I V}=\beta_{1}+\beta_{2} \frac{\gamma_{2}}{\gamma_{1}}
$$

This leads to an overestimate if the correlations between the instrument and the different institutions have the same sign. Indeed, since

$$
\operatorname{plim} \hat{\beta}_{O L S}=\beta_{1}+\beta_{2} \rho_{x_{1} x_{2}} \frac{\sigma_{x_{2}}}{\sigma_{x_{1}}},
$$

the IV estimator can have a larger upward bias than the OLS estimator.

Indices of institutions used in the cross-country literature are very strongly biased towards measuring the institutional environment facing urban, formal sector agents. In some cases this is explicit: Political Risk Services attempts to gauge the "risk of expropriation of foreign private investment by government." Other measures focus strongly on de jure procedures that may or may not govern actual behavior. The 'index of legal formalism' measures the number of formal legal procedures needed for collecting on a bounced check. Some might argue that the institutions facing agents in the formal sector are the most salient for the overall growth prospects of a country. However, the possibility that the de facto environment within which the majority of the population lives is at least as relevant suggests that omitted variable bias can be serious. 


\section{Heterogenous Treatment Effects}

A different concern relates to within country heterogeneity in the characteristics and operation of particular institutions. ${ }^{5}$ For instance, any measure of 'trust' will vary across communities and individuals within communities. Mechanisms of contract enforcement take very different forms for rural and urban entrepreneurs. The institutional framework within which corruption occurs is likely to operate very differently for multinational corporations and small-scale traders.

More formally, significant differences across and within countries in individual responses to institutions can significantly affect the appropriateness of using an IV strategy (Imbens and Angrist (1994), Heckman and Vytlacil (2000) and Manning (2004)). IV estimates capture the impact of the institutional variable on the growth outcomes of those countries in which the institutional outcome is sensitive to the value of the instrumental variables. The interpretation of the IV estimate as the average of the effect of the institution on growth depends on special assumptions on the way that countries respond to the institution and way that the institution responds to the instrument. A simple version of the model is

$$
y_{i}=\beta_{0}+\beta_{1 i} I_{i}+\varepsilon_{i}
$$

and we have available an instrument

$$
I_{i}=\gamma_{0}+\gamma_{1 i} z_{i}+v_{i}
$$

In this case both stages of the IV are characterized by heterogeneous effects. We know that (after we make the helpful assumptions that $\beta_{1 i}$ and $\gamma_{1 i}$ are independent of $\varepsilon_{i}, v_{i}$ and $z_{i}$, that $E\left(\gamma_{1 i}\right) \neq 0$ and that $\left.E\left(v_{i} \mid z_{i}\right)=E\left(\varepsilon_{i} \mid z_{i}\right)=0\right)$ :

$$
\hat{\beta}_{1}^{I V} \rightarrow^{p} \frac{E\left(\beta_{1 i} \gamma_{1 i}\right)}{E\left(\gamma_{1 i}\right)} .
$$

If $\beta_{1 i}$ and $\gamma_{1 i}$ are independent of each other, then $\hat{\beta}_{1}^{I V} \rightarrow^{p} E\left(\beta_{1 i}\right)$, which may be what we want. However, consider the following plausible form of heterogeneity. Suppose $\beta_{1 i}=\beta_{1}+\beta_{2} x_{i}$, where $x_{i}$ is some unobserved omitted variable that influences the effect of the institution on growth. We normalize $x_{i}$ to have mean zero. For example, suppose $x_{i}$ is some unobserved dimension of

\footnotetext{
${ }^{5}$ Brown and Guinnane (2005) discuss the deleterious consequences of analysis that obscures internal heterogeneity in the well-known European Fertility Project.
} 
precolonial history (such as the security of land tenure) that changes the effect of formal credit market expansion on growth. To fix ideas, $\beta_{2}>0$ - better tenure security increases the effect of credit markets on growth.

At the same time, of course, $\gamma_{1 i}=\gamma_{1}+\gamma_{2} x_{i}$, because the same omitted feature will influence the degree to which current institutions $\left(I_{i}\right)$ depend on our observed instrument (say, settler mortality). If $\gamma_{2}$ is also positive, the IV estimator will exceed the true causal effect. Specifically,

$$
\begin{aligned}
\hat{\beta}_{1}^{I V} & \rightarrow p \frac{E\left(\beta_{1 i} \gamma_{1 i}\right)}{E\left(\gamma_{1 i}\right)}=\frac{E\left(\beta_{1}+\beta_{2} x_{i}\right)\left(\gamma_{1}+\gamma_{2} x_{i}\right)}{E\left(\gamma_{1}+\gamma_{2} x_{i}\right)} \\
& =\frac{\beta_{1} \gamma_{1}+\beta_{2} \gamma_{2} \operatorname{var}(x)}{\gamma_{1}}=\beta_{1}+\frac{\beta_{2} \gamma_{2} \operatorname{var}(x)}{\gamma_{1}}>\beta_{1}=E\left(\beta_{i}\right)
\end{aligned}
$$

This simple example suggests that IV estimation techniques in the presence of hetereogeneity in institutional form within a single country can cause the IV to overestimate the true effect. Below, we use the example of land law in Africa to demonstrate that such within-country heterogeneity is commonplace in many low income countries.

\subsection{The Limitations in Practice}

We now examine two particular instances which illustrate the empirical relevance of these limitations of the cross-country methodology that has dominated this literature.

\section{A. Institutions and Poverty}

The typical institutions regression has GDP per capita as the dependent variable. As development economists, however, we should be at least as interested in the determinants of poverty. What can we learn by replacing GDP with a poverty measure, the head count ratio, in this canonical regression?

There is reason for some skepticism. As institutional measures tend to focus on the urban and formal sector, we would expect them to have less impact when we consider poverty, which depends particularly strongly on features of the rural and informal economy.

Table 2 reports these regressions. Our measure of institutional quality is 'Protection against Expropriation Risk' and we use log settler mortality as the instrument. Following Acemoglu, Johnson, and Robinson (2001) we start with the sample of 64 ex-colonies with settler mortality 
data. We have poverty data for 43 of these countries. Our poverty measure is the headcount ratio, defined as the percentage of the population living in households with consumption or income per per person below the global poverty line, defined as one dollar per day (Source: PovCal Net, World Bank). We use the median head-count ratio value, over 1981-2001 (typically, this ratio is reported at three year intervals). We also report results where we include the four OECD countries which were ex-colonies and set their headcount ratio to zero.

Panel A provides OLS results. We observe a strong and significant negative correlation between protection against expropriation risk and the headcount ratio. A one standard deviation increase in institutional quality reduces the percentage population that is poor by $10 \%$ in our base specification. This estimate is relatively unchanged by the inclusion of a geography control and continent dummies. Panel B provides 2SLS estimates, and Panel C the corresponding first stage regression. Excluding controls, the 2SLS estimate is twice the size of the OLS (column (1)) while with controls the 2SLS estimate is four times the size of the OLS estimate (column (3)). If we were to take the column (3) estimate seriously it would suggest that a one standard deviation increase in institutional quality would move the country from the 75 th to the 25th percentile of the distribution of the headcount ratio. This is a much more dramatic effect than is observed in the corresponding growth regression, where a one standard deviation increase in protection against expropriation leads to a 2.7 -fold increase in income, which corresponds approximately to a move from the $25 t h$ to the $50 t h$ percentile of the distribution of income per capita. It is very likely that settler mortality is correlated with other, unobserved, features of the rural environment that are much more important for poverty outcomes than the protection that foreign investors have against expropriation by the central government. These same omitted features of the rural environment may also be associated with a stronger treatment effect of the effect of improved security of formal property rights on rural poverty. In both instances, the IV estimator will overestimate the effect of these institutions on poverty.

\section{B. Land Law}

Aggregate formal sector based indices of institutional quality are unlikely to capture institutional quality as faced by the average person in developing countries. Further, heterogenous treatment effects may be a real concern in developing countries where social and ethnic networks remain 
an important constraint on individual decision-making.

To illustrate these concerns we describe property rights in land in four African countries. We choose the best and worst performing African countries according to the expropriation risk index used by Acemoglu, Johnson, and Robinson (2001). These are Gambia and the Democratic Republic of Congo (formerly Zaire, henceforth DRC). In addition we choose Ghana, a country we study in more detail below, and its neighbor Cote'd Ivoire. These two countries offer an interesting contrast of neighboring countries which were ruled by different colonial powers. The legal origins variable codes Ghana and Gambia as having English law, and DRC and Cote'd Ivoire as having French Law. Table 3 describes property rights in land for these four countries.

\section{(i) De Jure and De Facto Land Rights: The Importance of 'Customary' Law}

Measures of 'institutions' in the cross-country literature are typically based on either formal rules and procedures or perceptions of those working in the urban business sector. It is immediate from Table 3 that what matters for rural land rights is the country's community-based mechanisms as exemplified by customary law. The use of almost all land in these four countries is governed by customary tenure arrangements, not formal sector rules. The influence, if any, of the formal legal system introduced by colonial powers on land rights as experienced by households is indirect.

This is not to say that an analysis of de jure rights is uninteresting: such an analysis is essential for understanding the importance of changing formal laws regarding property, and such changes may an important instrument for policy. However, it is clear that any exercise examining the effect on economic activity of property rights as they are actually experienced by agents cannot restrict attention to the de jure legal system.

We observe a stark contrast between de jure and de facto property rights in these countries. French authorities typically did not recognize land ownership by traditional chiefs. In contrast, in colonies without significant white settlement, the British policy of indirect rule included (the colonists' interpretation of) customary land tenure rules. In terms of de jure laws, our Table suggests this is reflected in a more limited recognition of customary law in French colonized countries (DRC and Cote'd Ivoire). However, there is no close correspondence between 'legal origins' and de facto land tenure rights in these four countries. In the French colonized countries war seems to have played a more important role in defining the security of property rights. 
Further, a central tenet of customary law that, for most part, individuals cannot sell land on which they have user rights, remains relevant in the rural sector of all countries, save Cote'd Ivoire (for Gambia, see Freudenberger (2000), for Ghana, see of Lands and Forestry (2003), and for DRC, Moyroud and Katunga (2002)).

Equally, there is no clear relationship between 'average protection against expropriation' and the likelihood that a cultivator is confident of his or her control over land. While Gambia is a clear outlier in this group of four, categorized as having much higher protection against expropriation, use rights in some areas of the Gambia are less well-established than those in much of Ghana (in particular, use rights are very secure in Ghana's cocoa-producing areas). Protection against expropriation in the DRC is rated as extremely poor relative to that in Côte d'Ivoire, but tenure security seems to be quite similar in areas of both countries less affected by their respective wars.

\section{(ii) Land Rights are Heterogeneous Within Countries}

Customary law has nearly full legal recognition in Gambia (Freudenberger 2000), and none in the DRC (Leisz 1998). In Ghana and Côte d'Ivoire it has only partial recognition. Further, the complexity of de facto land rights hinders the interpretation of "secure property rights". Customary law tends to view land and resources as inalienable, such that property rights cannot be wholly ceded by those to whom the land has been allocated (Bruce and Migot-Adholla 1994b). As a consequence, in none of the countries included in Table 3 is anything approaching freehold tenure common in agriculture. In Côte d'Ivoire, land sales are generally permitted by customary law(Kone 2002), which could appear to be an indication of more secure tenure than exists in most of Ghana. However, usufruct rights are generally secure in most of Ghana while the land is under cultivation (even including tree crops) (Amanor 1999), while the usufruct rights of the large population of non-Ivoirian migrants in Côte d'Ivoire are very insecure (Chauveau 2000). Apparently, property rights over land are more secure in Ghana than in Côte d'Ivoire for some individuals, while for others the opposite is true. Within any of the countries listed in the table there is a distribution of tenure security; clearly, the usefulness of summarizing that distribution with a single index is sensitive to the context and the economic model.

Further, the same piece of land can be subject to multiple claims which relate to the ways 
in which it is used by separate groups and individuals at different levels. For example, one individual may have the right to cultivate annual crops on a plot, while another retains rights to the tree crops that exist on the same land. An elder might have the right to allocate a plot to a family member for temporary use, but not the right to rent the plot to an outsider on a commercial basis. Property rights are typically multidimensional and collapsing this down to a single index might be misleading in important ways.

\section{(iii) Political and Contractual Institutions are Intertwined}

A common distinction in the cross country institutions literature has been between political institutions (as measured by, say, expropriation risk), and institutions which determine contractual form (as measured by, say, legal origins). However, the real world is much more complicated, and, in particular, this distinction is treacherous when considering land rights in Africa. Indigenous tenure principles are implemented and arbitrated by authorities (chiefs, lineage heads, elders) whose legitimacy is typically drawn from a local political process. Their authority over land allocation is political power, since it enables them to give or refuse a farmer the right to cultivate or to settle. "By allowing or forbidding newcomers to settle and by fitting them, from the outset, within a network of alliances, the land chief regulates the process where a local community is constituted" (Raynaut 1997, 289-290).

Specific property rights as experienced by farmers often depend on both how political office is allocated and the land allocation powers given to the politician (Udry and Goldstein 2004). Thus, political and contractual institutions seem to be fundamentally intertwined for land tenure processes in Africa. Importantly, the nature of such intertwining varies significantly across countries. This again suggests heterogeneity in the effect of institutions across countries.

The extraordinary diversity of institutional practices across and within countries places natural constraints on the usefulness of cross-country analyses for understanding the specific channels through which institutions affect economic outcomes, and how these institutions, in turn, respond to economic, demographic, political and social forces. 


\section{Within-Country Institutional Variation}

Recent years have seen an explosion in empirical research in development economics. One of the most fruitful areas of research has been program evaluations in developing countries - these typically combine household or regional level data with detailed information on the implementation of a particular institution or policy in the country to estimate its economic impact. In this section we discuss how this line of research can both compliment and advance the research agenda suggested by the institutions and growth literature.

Table 4 lists some recent papers which study potential within-country counterparts of the main institutions studied in the cross-country literature. ${ }^{6}$ While our literature review is nonexhaustive, it is clear from the Table that many synergies exist between the cross-country and within-country literatures.

Relative to cross-country analyses, an important advantage of within-country studies is the relative homogeneity of the institutional and constitutional setting across the units of analysis. This potentially helps disentangle the economic impact of institutions from unobserved heterogeneity across the units of analysis. In addition, concerns of heterogenous treatment effects may be more limited in the context of a single country. Finally, and we would argue most importantly, the scope for identifying credible instruments for particular institutions is much greater in the case of within-country studies. The reason is that institutional change is typically implemented at the country (or sub-country) level. This opens up the possibility of exploiting specific features of how institutional change was implemented across regions in a country or across different population groups to obtain instruments for the institutional variable of interest. In contrast, both the choice and implementation of public policies varies significantly across countries. Hence, using any single country's experience with institutional change to identify instruments for a cross-country analysis will typically not yield an instrument with sufficient

\footnotetext{
${ }^{6}$ We restricted attention to the journals considered in the cross-country literature review and did a Google scholar search where the keywords were institutions and development. We also manually reviewed the issues of American Economic Review, Quarterly Journal of Economics and Journal of Political Economy for 2002-2004. Given this set of papers, we then used our judgement to identify papers which provide a within-country counterpart to the main institutions covered in the cross-country review. In a couple of cases, we have augmented the list with recent unpublished papers.
} 
power across a large number of countries. Hence, the reliance on relatively crude instruments such as settler mortality.

As is apparent from Table 4, a common approach is to use panel data which spans years both before and after the policy change and to exploit cross-sectional variation in the extent of institutional change. Such variation may arise due to timing differences in policy implementation across different regions within the country, or because the extent of institutional change was explicitly related to underlying economic features of the regions. The canonical regression in this literature is of the form

$$
Y_{s t}=\alpha_{s}+\beta_{t}+\gamma I_{s t}+\epsilon_{s t}
$$

where $s$ denotes regions within a country and $t$ time. $Y_{s t}$ is the outcome of interest and $I_{s t}$ the relevant institution. The inclusion of regional fixed effects $\left(\alpha_{s}\right)$ accounts for permanent differences between regions and time fixed effects $\left(\beta_{t}\right)$ for shocks which affects all regions. This regression specification can not, in itself, allay the concern that the institutional variable and the economic outcome of interest are both affected by some omitted time-varying region-specific variable. That is, $E\left(I_{s t}, \epsilon_{s t}\right) \neq 0$ (Besley and Case 2003). One may also be concerned about the external validity of such a study - a study which focuses on institutional change within a country may not be informative of the true average effect of the institution (that country may, for instance, be much poorer than the average country in the world).

To assess whether within-country studies can address these concerns we focus in on the literature on a single institution - private land rights. Table 5 provides a non-exhaustive summary of papers analyzing the economic impact of land titling and registration, organized by country. ${ }^{7}$ To identify the economic impact of land titling it is common to exploit the passage of land titling or registration programs which take land claims out of the realm of informal lineage, community land ownership or informal 'squatter' rights and making them legal, formal and individual (Binswanger, Deninger, and Feder 1995)

These studies span numerous countries and a multitude of different economic settings. Thus, while the external validity of any single study may have limits it is certainly possible to compare

\footnotetext{
${ }^{7}$ In selecting papers for this Table our aim was to show the richness of country experiences with land titling programs.
} 
across studies in different regions to identify generalizable lessons. Looking across the studies suggests the following findings:

- Land titling and registration typically increase agricultural productivity and farm investment. However, the extent of this increase depends upon the details of the titling program and the pre-existing land tenure system.

- There is a weaker, but usually positive, effect on credit. The impact of titling on credit is very limited in situations with less developed credit markets.

- There is some evidence that land value rises, but this remains very preliminary.

It is clear that endogenous uptake of land titles presents a serious concern for empirical evaluations, and that not all papers address this concern adequately. However, the potential for using the institutional details of the land titling intervention to identify credible instruments for exposure to land titling far exceeds that available in the context of a cross-country study. A good example is Field (2003a) who analyzes the value to a squatter household in Peru of increases in tenure security associated with obtaining a property title as measured by his/her labor supply response. A national titling program in Peru issued formal property titles over a five-year period to more than 1.2 million urban households. Field uses two sources of variation in program influence to isolate the effect of titling: neighborhood program timing and program impact based on prior household ownership status. In particular, staggered regional program timing enables a comparison of households in neighborhoods already reached by the program with households in neighborhoods not yet reached. She combines these facts with data on past and future title recipients (collected half way through the titling program) to identify a natural set of comparison groups composed of treated and yet-to-be-treated households. A comparison of the labor supply behavior of these two sets of households can be interpreted as reflecting the causal effect of land titling. Similar empirical methods are used by Banerjee, Gertler, and Ghatak (2002) in the context of India and Do and Iyer in the context of Vietnam. The absence of a unifying institutional environment implies that such studies could not be undertaken at the cross-country level.

Finally, the fact that the economic effect of land titles depends on the existence of complimentary institutions, the details of the titling program and the pre-existing land tenure system 
points to the importance of accounting for heterogenous effects. It would appear that an important and relatively unexplored area for research is to use within-country studies to better understand the source of such heterogeneity. ${ }^{8}$

\section{Within Institution Variation: Insecure Property Rights in Ghana}

A given institution can provide a variety of incentives to different individuals, depending on their endowments. This makes it possible to use data on the behavior of individuals within a given institutional setting to explore the consequences of an institution for behavior, and potentially of changing factor endowments for institutional form. In this section we use household survey data from Ghana to provide one example of such research.

Over 60 percent of the Ghanaian population is in the agricultural sector, and land distribution is mostly governed by customary law. Under customary law, land is often regarded as a common asset and resource. Individual ownership is recognized for standing crops, but not for the soil itself. Rather, ultimate title over land is vested in corporate groups, in particular in the lineage, and individuals gain access to land via membership in such groups. There are multiple potential claimants to any particular plot; competing claims are negotiated and certain members of the community are recognized as having the power to arbitrate such conflicts. Land rights in the study area are complex, ambiguous and highly negotiable (Udry and Goldstein 2004). Given this, we examine how micro-data can be used to understand the implications of this land tenure system for investment and agricultural productivity. Further, we explore whether changing factor endowments in Ghana have affected the cost of having insecure property rights, and the responses of political actors and citizens.

\subsection{The Investment and Productivity effects of Land Rights}

Our data comes from a two year rural survey in the Akwapim South District of the Eastern Region of Ghana conducted by Goldstein and Udry (for survey description and data, see

\footnotetext{
${ }^{8}$ We also note that the equity effects of titling remain very controversial; so far, there has been little research that effectively identifies the long run relationship between titling and the distributions of wealth and income.
} 
www.econ.yale.edu/ ${ }^{\sim}$ cru2/ghanadata.html).

The main farming system is an intercropped mixture of maize and cassava, which is cultivated for both home consumption and sale through a well-developed marketing system. Land productivity is managed primarily through fallowing; cultivation is periodically stopped in order for nutrients to be restored and for weeds and other pests to be controlled. An element of the land tenure system that plays a key role in the evolution of its agricultural economy is that cultivators have historically had very secure rights over their growing crops (both tree crops and

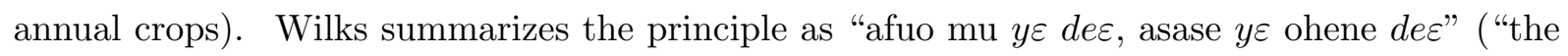
farm is my property, the land is the stool's").

However, the lineage leadership may reallocate fallow land to other members of the lineage. The details of this allocation process are unique to the local context, but many of its broad features arise frequently in African (particularly West African) land tenure systems. ${ }^{9}$ In our study area land is held by the abusua, which is defined by matrilineal descent, on the authority of the paramount chief (or stool). The leadership of the matrilineage is locally-based and is responsible for allocating use rights within a village to members of the matrilineage. ${ }^{10}$ The allocation of land within the matrilineage is rooted in local politics and social relations. ${ }^{11}$

Land allocation is, thus, a political process that operates at the level of the local matrilineage. Cultivators on the margins of local political power - those who hold no form of local political office - are less confident of their rights over land than those who have local political office. Table 6 presents evidence of this difference in confidence. ${ }^{12}$

(Udry and Goldstein 2004) use these survey data to establish that insecurity of land tenure is associated with lower investment in land and hence reduced agricultural production. Table 7 summarizes the main consequences of this difference in tenure security for fallowing behavior and hence for output. Conditional on observed characteristics of the plot, office holders leave plots fallow for approximately 2 years longer than non-officeholders, and each additional year

\footnotetext{
${ }^{9}$ Fred-Mensah (1996); Biebuyck (1963);Bruce and Migot-Adholla (1994a); Binswanger, Deininger, and Feder (1995); Bassett (1993); Peters (1994) and Bruce and Migot-Adholla (1994a)Bromley (1989)

${ }^{10}$ In our sample leaders tend to be male and older than other members of our sample, but no more likely to be educated.

${ }^{11}$ (Berry 2001, 145)

${ }^{12}$ There is a wide variety of local political offices held by individuals in our sample. Typical offices include lineage or village head or elder.
} 
of fallowing is associated with an increase in plot profits per-hectare of over 300 thousand cedis (compare this magnitude with the mean gross output per hectare of about 1.2 million cedis, or to per-capita GDP of approximately 700 thousand cedis). (Udry and Goldstein 2004) estimate the magnitude of the loss associated with this inefficient fallowing to be approximately one-third of output. ${ }^{13}$ Some plots are obtained through commercial transactions (about half through fixed-rent contracts, and half through sharecropping), rather than through the allocation of matrilineage land. If we look (in column (3)) at fallow duration by form of land allocation we observe that commercially-obtained plots are fallowed for longer (slightly over half a year). Further, office holders and non-office holders exhibit similar behavior on commercial plots. In column (4) we continue to observe increased fallowing of commercial plots when we compare across different plots cultivated by an individual farmer.

\subsection{The Evolution of Land Rights}

The insecurity of land tenure in this farming system is associated with a very large cost of lost output. Why, then, did it emerge and does it persist?

\section{A. Background}

The abusua-based land tenure system in southern Ghana emerged before the 19th century, as part of a political system in which political power flowed through the matrilineage. ${ }^{14}$ During

\footnotetext{
${ }^{13}$ See (Udry and Goldstein 2004) for full details of the econometric procedures. These estimates are all conditional on household*year fixed effects (except column 4, which uses finer individual fixed effects) because imperfect factor markets in these villages imply variation across households in the shadow costs of factors of production. Each also includes spatial fixed effects (with neighborhoods defined as a distance of 250 meters) to better account for unobserved variation in land characteristics. Estimates are also conditional on a set of plot characteristics including deciles of plot area, and indicators of soil type, and toposequence. The magnitude of the production loss is based on estimates of a concave production function specified as $\pi_{i t}=\mathbf{X}_{i p} \beta+g\left(d_{i t}\right)+\lambda_{h_{i p}, t}+\epsilon_{i p t}$, where $X_{i t}$ includes the control variables listed above, $\lambda$ is the household*year fixed effect, and $d_{i t}$ is the fallow duration on plot $i . \quad g(d)$ is specified as $g\left(d_{i t}\right)=\left\{\begin{array}{cl}\alpha \ln \left(d_{i t}+\gamma\right)-\frac{\alpha}{7+\gamma} d_{i t} & \text { for } d_{i t} \leq 7 \\ \alpha \ln (7+\gamma)-\frac{\alpha}{7+\gamma} 7 & \text { for } d_{i t}>7\end{array}\right.$ where the $2 n d$ term ensures that the derivative of the function is 0 at $d_{i t}=7$, because of evidence in the soil science literature from this region that fallow periods longer than 7 years are unlikely to have further positive effects on farm productivity.

14 "The elementary level of political organization in precolonial Asante ... was the matrilineage (abusua, pl. mmusua). It was through membership of an abusua that free (non-slave) Asantes were integrated into the polity.
} 
this period, and even into the early 20th century, "land for cultivation was abundant in the strict sense that the marginal product of land must have been zero. ...[F]rom what is known of the soils, crop repertoire and farming techniques, fallows were long enough for full restoration of soil fertility." (Austin 2004, p. 64.). Even in the most densely-populated areas of southern Ghana (near Kumasi, the capital of the Asante state), population densities were under 30 people per square kilometer, permitting average fallow periods of over a decade. The role of the matrilineage leadership was to secure the rights of cultivators to cultivated plots. This they did; while cultivators could have no expectation of re-establishing cultivation on a fallowed plot, the investment of labor in clearing and cultivating a plot ensured that the farmer would retain control over the plot until it was fallowed.

The early years of the 20th century saw southern Ghana become the world's largest grower of cocoa (Hill 1963). Between 1910 and 1940, thousands of people made substantial longterm investments in cocoa trees, which began to reach maturity after $5-7$ years, and could continue to produce for decades. These investments were facilitated by a fortuitous concurrence between the land tenure system and the agronomic characteristics of cocoa. The security of an individual's rights over a cultivated plot was long-established, and was reinforced during the early $20 t h$ century by both the newly-established British colonial government and by the Councils of Chiefs. Once planted, cocoa often stood on a plot for decades. While it stood, the cultivator's rights to use, rent, or mortgage the plot were secure. ${ }^{15}$

Over the 20th century, the first signs of the elimination of land abundance began to emerge. Fallow periods for land not under cocoa cultivation began to decline, and disputes between matrilineages or between chiefs over the boundaries of their land became more common (Firmin-Sellers 1996)(Berry 2001). While these disputes engaged higher-level political actors, the usufruct rights of cultivators were protected; "farmers kept their farms even when their chief had been defeated in litigation over the ownership of the land" (Austin 2004, p. 277).

As long as cocoa remained the foundation of the rural agrarian economy, neither the colonial state nor the immediate post-independence government proceeded with any formal effort to privatize or title rural land. There were three crucial reasons for this. First, both chiefs and

The matrilineage head owed allegiance to a sub-chief." (Austin 2004, p. 35).

${ }^{15}$ (Austin 2004, p. 269). 
government officials expressed fear that a consequence of titling would be the establishment of a landless class. Whatever inefficiencies might be associated with the complex and ambiguous land tenure system existing in Ghana, the principle that all members of a local corporate group are entitled to cultivate land ensured that no substantial disenfranchised group of landless persons ever emerged. Second, the effort would involve substantial administrative costs. Third and most important, there was no apparent need for privatization. "It is evident that the land tenure system $[\mathrm{s}]$, both in the Gold Coast Colony and in Asante, offered cocoa farmers what they regarded as sufficient security of tenure to make very widespread long-term investments" (Firmin-Sellers 1996, p. 346).

However, by the 1970s, the cocoa economy was in full-fledged collapse, due primarily to extraordinarily high rates of explicit and implicit taxation of exports (Aryeetey, Harrigan, and Nissanke (2000)Bates (1981)). Farmers across Ghana exited cocoa production and increased production of food crops. At the same time, land scarcity was becoming increasingly evident. As cultivation switched from a tree crop to annual food crops, the key to maintaining soil fertility and hence productivity became sufficient fallowing. Therefore, the insecurity of rights over fallowed land was beginning to have important costs. During this period, however, the administrative structure of the Ghanaian state itself was near collapse(Aryeetey, Harrigan, and Nissanke 2000). The national government simply did not have the capacity for a significant land titling program, and thus focused its few resources on registering urban land ${ }^{16}$.

The inability of the national government to implement a titling program that would resolve the ambiguities of the land tenure system is apparent, but the lack of a local solution to the inefficiencies uncovered above is more puzzling. In our study area, the transition from cocoa to the intercropped mixture of maize and cassava occurred much earlier than in most of Ghana. Although Akwapim was the first location in Ghana to adopt cocoa on a large scale at the start of the 20th century, it is not particularly well-suited for cocoa cultivation. By the 1940s, a devastating outbreak of swollen shoot disease had led to the breakdown of the local cocoa farming system, and maize and cassava production for sale to local urban markets became the mainstay of local agriculture.

\footnotetext{
${ }^{16}$ There are formal procedures for land registration, defined in the 1986 Land Title Registration Law (PNDCL 152), but these are virtually never used outside urban areas.
} 


\section{Insecure Land Tenure as a form of Social Security}

It is clear that understanding the persistence of this land tenure regime requires an understanding of the local political economy under which it exists, and of the role that this land tenure system serves beyond its effect on investment incentives. Historically, an important source of resistance to titling has been the fear that landlessness would result. An important rationale for the allocation of land use rights via membership in the matrilineage is redistribution. Limited access to credit markets remains pervasive in rural Ghana, and so land redistribution is seen as essential to preventing long term poverty

An important mandate of local political leaders is to prevent landlessness. The flexible land tenure system has successfully prevented the emergence of a landless class. ${ }^{17}$ Given imperfections in other factor markets, the efficiency gain from equalizing land ownership per capita across households can potentially offset some of the loss associated with reduced fallowing due to insecurity of tenure rights. Lack of panel data that tracks households over very long periods prevents us from directly examining the degree to which land is reallocated in response to demographic shocks. However, detailed data on the demographic composition of households suggests that the magnitude of demographic shocks is not large enough to make this an efficient mechanism. Nevertheless, it is clear that there are gains associated with this kind of redistribution in response to demographic shocks, and perhaps a more diffuse gain associated with the lack of any landless class.

In the cross-section, we see little correlation between allocations of matrilineage land and the demographic composition of households. The only strong correlations we find are that households with older and more politically-powerful heads have more land. There is little evidence of important differences in living standards as household demographics change; per-capita expenditures decline weakly with household size and strongly with the ratio of children in the household.

In informal conversation, people in the study area claim that the allocation of land by the abusua leadership is driven at least in part by one's 'need'. Any member of the abusua who needs land is entitled to some for cultivation. The determination of "need", not surprisingly, is

\footnotetext{
${ }^{17}$ Only two households in our sample have no land; in both cases the husband has an office job and the wife is a trader.
} 
often contentious. The claim was made by several of our respondents that the act of leaving a plot fallow would demonstrate a lack of sufficient need, and therefore cast doubt on one's right to the plot. If this claim is true, then it must be the case that 'need' is private information, and that the extent of one's need can be signalled by choices with respect to fallowing.

It is apparent that there is far from complete information about individuals' resources in rural Ghana. Most adults in rural Ghana engage in non-farm activities to complement their direct income from agriculture. In our sample, 65 percent of adults and almost 80 percent of women earn income from non-farm activities. Small-scale trading is the dominant activity of this type. Information regarding the income that is generated from non-farm activities is closely-held; even spouses are unlikely to know the details of one's incomes and expenditures from nonfarm enterprises (Goldstein 2000, chapter 1). Therefore, we assume that the matrilineage leadership cannot observe directly the extent of an individual's 'need' for additional land.

The abusua leader seeks to keep matrilineage land for his own personal or commercial use, while meeting his obligation to provide land to matrilineage members who have high need for that land. These are individuals have particularly low return off-farm opportunities - the poor. Failure by the leadership to allocate land to a sufficiently high proportion of the poor exposes the leaders to political penalties in the future. Hence, the leader seeks to allocate land to as many of the poor as possible, while keeping it out of the hands of the rich. We are motivated in this assumption by the observation that chieftaincy disputes, and disputes between villagers and abusua leaders, often center around perceived misallocation of abusua land by the leadership ( (Berry 2001, chapter 2); Benneh (1988)).

We hypothesize that the leadership uses a cultivation requirement to construct an incentivecompatible mechanism that separates (most of) the poor from (most of) the rich. The leadership offers land to those who will cultivate it without leaving it fallow. Keeping a plot in cultivation requires farming effort and thus lost income from nonfarm activities. The rich are generally unwilling to accept this contract: the sacrifice of their high nonfarm income would outweigh the benefit of cultivating poorly-fallowed land. The poor, however, typically find the tradeoff worthwhile and accept the land. ${ }^{18}$

\footnotetext{
${ }^{18}$ See (Berry 2001, chapter 2) for a formal treatment of the model. The model is related to that of Banerjee (1997). In his model, monetary rents are extracted from the rich, while here it is land that is captured. The
} 
The abusua leader can set the cultivation requirement to be more or less stringent. He has a certain amount of land that he can allocate. He has an obligation to allocate a unit of land to each poor farmer; this is the core social contract. If he fails to allocate land to the poor, he faces possible penalties in the form of litigation costs of defending himself in a chieftaincy dispute, or gifts and favors to the abusua elders to induce them to ignore the complaints. His problem is that he can not observe the off-farm earnings of most of the members of the abusua. If he offers land with no conditions, of course the entire population will accept the land. Hence, he uses the cultivation requirement to attempt to screen out rich members while still getting land to the poor.

The tradeoff is clear: an increases in the cultivation requirement increase the amount of land available for the leader to cultivate, but also increases the number of the poor who are not allocated land and hence the probability that the leader will be penalized. His choice is guided by balancing these conflicting objectives.

This model of land allocation has features that correspond well to both the informal accounts of tenure insecurity that we received from cultivators themselves, and to patterns of investment behavior that are evident in our data. In column 1 of Table 8 , we show that individuals who talk frequently (at least twice a week) with office holders have fallowing behavior that is essentially indistinguishable from office holders themselves. This is consistent with the idea of a cultivation requirement that is imposed as a way of distinguishing the poor from the rich among those about whom the officeholders have incomplete information. Officeholders have better information regarding the resources of those with whom they interact sufficiently intensively, and hence need not impose this costly revelation device. This result is also consistent with officeholders sharing rents with their friends.

As matrilineage land resources become more scarce (relative to the matrilineage population), the leadership will impose stricter cultivation requirements. The marginal value of additional land kept under their own control rises as land becomes more scarce, so the leadership is more willing to risk the penalty associated with failure to allocate land to some of the poor. Therefore, the gap between the fallow durations of non-office holders and office holders would tend to be larger in matrilineages in which land is more scarce. In column 2 of table 8 , we see unsurprisingly public observability of fallowing choices in our context is at the root of this difference. 
that fallow durations are, in general, shorter in more densely-populated matrilineages. In column 3 , we observe that the difference in fallowing by office holders and others rises with population density in the matrilineage. The interquartile range of the number of households per hectare in a matrilineage is approximately 1.5. These estimates imply that officeholders in a 'poor' matrilineage (at the 75th percentile of households/hectare) have a fallow duration about 5 years longer (relative to other households in the matrilineage) than households in a 'wealthy' matrilineage at the 25 th percentile of households/hectare.

These results suggest that increasing population density has affected the economic well-being of non-office holders more than that of office-holders. We next examine whether office-holders actually do better in more densely populated matrilineages. Table 9 suggests this is not the case. As we expect, leaders in matrilineages with more land per capita are better educated, farm much more themselves, have larger families, and maintain consumption per capita in their families. However, in contrast with the model, the gap between the education, area cultivated, household size, and per capita expenditure of officeholders and the rest of the population increases with the availability of land in the matrilineage.

To summarize, it appears that the flexible system of allocating temporary usufruct rights through a political process at the matrilineage level has served a reallocative purpose, helping avoid the emergence of a class of destitute landless in the villages. We also find evidence that this system is inefficient, with the cost of inefficiency mainly borne by those not holding political office. Finally, we find the efficiency cost of this system of insurance is apparently increasing with population density. Moreover, it appears that village leaders do worse in more land scarce matrilineages, suggesting that this may be an environment where the local population and leaders share a common interest in improving the security of property rights.

The transition away from a system of insecure property rights may take many forms. We begin by noting that as land gained value over the course of the early 20th century, both the courts and the chieftaincy councils maintained two principles that checked the opportunism of the contemporary generation of matrilineage leaders. First was a strict prohibition on the sale of land to outsiders without approval from higher-level authorities. All land under the control of a particular matrilineage was granted to it by a higher-level chief (called a 'stool') who retained a superior form of ownership: “... what we may call inferior ownership meant 
that a lineage owned its land subject to continued performance of its members' obligations as subjects, and acknowledgement of the ultimate and reversionary claim of the village headman or stool which had originally granted it the land." (Austin 2004, 101.) (also see (Berry 2001, 146-7)). It was the obligation of the stool to ensure that land remained available for the use of his subjects; therefore, only he had the right to sell land to outsiders. There is no question that a number of stools have sold land to outsiders, particularly in urban areas, but in general such sales have been rare and when attempted have often resulted in the destoolment of the chief (Berry 2001). Second was a resistance to granting permanent rights to land over local individuals. Current leaders could not guarantee cultivators the right to restart cultivation after fallowing. The most visible mechanism used to inhibit the transfer of long-term rights was the prohibition on permitting land to move outside the matrilineage via patrilineal inheritance. In most lineages the leadership carefully monitored allocated land to ensure that it was not passed down from father to son. This was often a source for land disputes, because fathers were generally permitted to 'lend' matrilineage land to their sons for brief periods (Austin 2004, 174).

In effect, these two restrictions have acted as formal barriers to abusua leaders using their powers to create more permanent property rights. Pervasive imperfections in capital markets have also limited this transformation. The large inefficiencies associated with the uncertainties of tenure security imply the existence of substantial gains if the matrilineage leadership could guarantee long-term tenure security. However, the benefits from this transformation would be spread far into the future, over a period of decades. With imperfect capital markets, the cultivators receiving long-term tenure security would not be able to pay the present value of this long-term gain. Nor could they commit to a long-term stream of future payments, for the same limited commitment reasons that long-term capital markets are so imperfect in these villages. ${ }^{19}$

The barriers to movement towards long-term security of land tenure are substantial. Nevertheless, we do observe cross-sectional evidence that villagers find ways around these barriers where they are particularly costly. In column 1 of Table 10, we show that individuals in matrilineages that have particularly intense population pressure on matrilineage land spend more

\footnotetext{
${ }^{19}$ Binswanger and Rosenzweig (1986) use this same argument in their discussion of the development of freehold tenure in land abundant agriculture.
} 
time on non-farm activities than individuals in less densely-populated matrilineages. Officeholders are exempt from this pattern - they spend more time on non-farm activities in less densely-populated matrilineages. This is in line with our model, which suggests office holders will place more stringent fallowing requirements and extract more land in a more densely populated abusua. And it is in those matrilineages that the fallowing behavior of office holders and others differs the most that individuals will concentrate their time on nonfarm activities.

In column 2 of Table 10, we show that farmers in more densely-populated matrilineages are more likely to use commercial transactions to obtain land. Recall that in Table 7, we showed that fallowing choices on commercial land are independent of officeholding status, and that (within individuals) fallow periods on commercially-obtained plots are substantially longer than on abusua land. Therefore, we see that in those matrilineages in which abusua land is under more severe population pressure (and that have shorter fallow periods, as seen in Table 10, a larger proportion of cultivated land is obtained through commercial fixed-rent and sharecropping contracts. Office-holders, on the other hand, do not respond to population pressure by moving towards cultivating commercially-obtained land, because (as in ??) they use their control over the land allocation process to mitigate the consequences of that pressure.

These results must be considered tentative, because they depend on variation at a given moment in time across a very limited number of matrilineages. However, they are suggestive that population pressure is inducing actions that may have the long-term consequence of transforming the land tenure system of the study area.

\section{Conclusion}

Gross correlations between institutional development and growth observed in cross-country data have provided a persuasive case that long-run growth is faster in countries that have higher quality contracting institutions, better law enforcement, increased protection of private property rights, improved central government bureaucracy, smoother operating formal sector financial markets, increased levels of democracy, and higher levels of trust.

This literature also suggests that understanding the channels of influence, and why such extreme variation in institutional quality persists are research questions of central importance. 
However, the scope of using cross-country data for identifying the channels of influence is limited. The measurement of 'institutions' at the country level is necessarily coarse, and obscures important dimensions of heterogeneity. Even more important, there are very few plausible sources of exogenous variation in country-level institutions that can serve to identify the causal effect of institutions on growth. It is this fact that in the end most severely limits the range of questions that can be addressed with this methodology. For instance, a paper which relies on institutional persistence to obtain instruments for institutional quality will be hard pressed to identify institutional evolution. Further, we argue that due consideration must be given to the appropriate unit of analysis when considering the relationships between institutions and economic activity. A unit smaller than a country may provide a more homogeneous environment for a given institution, and therefore reveal more about the causal role of that institution.

These observations lead us to point to the empirical research based on micro-data in development economics and suggest that the research methodologies pursued in this literature can help make progress on the above issues. One such opportunity is presented by country-specific policies that implement institutional change. Exploiting within-country variation implies a focus on a more homogenous environment. Further, it is often possible to exploit features of the policy implementation process to obtain instruments which can help isolate the effect of a specific institution.

A given institutional setting can provide a rich variety of incentives to different individuals, depending upon their economic, social or political position. In section 4 we provide an example from Ghana. We describe the complex land tenure system that exists in one region of Ghana. In this system, individuals have very different levels of tenure security, depending upon their position in a local political hierarchy. We show how this variation in the degree of security can be exploited to identify the implications of tenure security for investment in land. We also discuss the historical evolution of this land tenure system, and provide some evidence regarding actions that individuals are currently taking to mitigate the dramatic inefficiencies associated with tenure insecurity. Our evidence suggests that these actions have the potential to transform the land tenure system of the region, and suggest that a close examination of individual actions may help us understand how institutional change is initiated in economic environments facing changing economic and demographic pressures. 
References

Acemoglu, D., S. Johnson, and J. A. Robinson. 2001. The Colonial Origins of Comparative Development: An Empirical Investigation. American Economic Review 91, no. 5:1369-1401.

Acemoglu, Daron. 2005. Constitutions, Politics and Economics: A Review Essay on Persson and Tabellini's "The Economic Effect of Consitutions". Journal of Economic Literature.

Acemoglu, Daron, Simon Johnson, and James A. Robinson. 2002. Reversal of Fortune: Geography and Institutions in the Making of the Modern World Income Distribution. Quarterly Journal of Economics 117, no. 4:1231-1294.

Acemoglu, Daron, and Simon Johnson. 2005. Unbundling Institutions. Journal of Political Economy 113, no. 5:949-995.

African Development Fund. 2004. Democratic Republic of Congo: Agricultural and Rural Sector Rehabilitation Support Project in Bas-Congo and Bandundu Provinces (PARSAR) Appraisal Report.

Aghion, Philippe, Peter Howitt, and David Mayer-Foulkes. 2005. The Effect of Financial Development on Convergence: Theory and Evidence. Quarterly Journal of Economics 120, no. 1:173-222.

Aide et Action pour la Paix. 2004. Ce Qu'il Faut Connaitre Sur le Sol en Droit Congolais.

Alston, Lee J., Gary D. Libecap, and Bernardo Mueller. 2000. Land Reform Policies, the Sources of Violent Conflict, and Implications for Deforestation in the Brazilian Amazon. Journal of Environmental Economics and Management 39, 162-188.

Alston, Lee J., Gary D. Libecap, and Robert Schneider. 1996. The Determinants and Impact of Property Rights; Land Titles on the Brazilian Fronteir. Journal of Law, Economics and Organization 12, no. 1:25-61.

Amanor, Kojo S. 1999. Global Restructuring and Land Rights in Ghana: Forest Food Chains, Timber and Rural Livelihoods. Vol. 108. Uppsala: Nordiska Afrikainstutet.

Antle, John, et al. Endogeneity of Land Titling and Farm Investments: Evidence from the Peruvian Andes. Bozeman, MT: Department of Agricultural Economics and Economics, Montana.

Aportela, F. 1998. Effect of Financial Access on Savings by Low-Income People.Massachusetts Institute of Technology.

Aryeetey, Ernest, Harrigan, Jane, and Nissanke, Machiko. 2000. Economic Reforms in Ghana : The Miracle and the Mirage. Oxford :James Curry ; Accra, New Town, Ghana: Woeli Publishing Services; Africa World Press.

Asiama, Seth O. 2003. Comparative Study of Land Administration Systems: Case Study - Ghana.UK Department for International Development. 
Austin, Gareth. 2004. Labour, Land, and Capital in Ghana : From Slavery to Free Labour in Asante, 18071956. Vol. 18. Rochester, NY: University of Rochester Press.

Banerjee, Abhijit V. 1997. A Theory of Misgovernance. Quarterly Journal of Economics 112, no. 4:12891332.

Banerjee, Abhijit V., Paul J. Gertler, and Maitreesh Ghatak. 2002. Empowerment and Efficiency: Tenancy Reform in West Bengal. Journal of Political Economy 110, no. 2:239-280.

Barro, Robert J., and Lee, Jong-Wha. Data Set for a Panel of 138 Countries. 1999Available from http://post.economics.harvard.edu/faculty/barro/data.html.

Bassett, J. T. 1993. Cartography, ideology, and power: the World Bank in northern Côte d'Ivoire. Passages: A Chronicle of the Humanities.

Bates, Robert H. 1981. Markets and States in Tropical Africa : The Political Basis of Agricultural Policies. Berkeley: University of California Press.

Beck, Thorsten, Asli Demirguc-Kunt, and Ross Levine. 2003. Law, Endowments, and Finance. Journal of Financial Economics 70, no. 2:137-181.

Bell, C., and P. L. Rousseau. 2001. Post-independence India: a case of finance-led industrialization? Journal of Development Economics 65, no. 1:153-175.

Benneh, George. 1988. The Land Tenure and Agrarian System in the New Cocoa Frontier: Wassa Akropong Case Study. In Agricultural Expansion and Pioneer Settlements in the Humid Tropics, edited by Walther Manshard and William B. Morgan. Tokyo: The United Nations University.

Berry, Sara S. 2001. Chiefs Know Their Boundaries : Essays on Property, Power, and the Past in Asante, 1896-1996. Portsmouth, NH :Heinemann ; Oxford; Cape Town: J. Currey; D. Philip.

Besley, T., R. Pande, and V. Rao. 2005. Participatory Democracy in Action: Survey Evidence from South India. Journal of the European Economic Association 3, no. 2-3:648-657.

Besley, Timothy. 1995. Property Rights and Investment Incentives: Theory and Evidence from Ghana. The Journal of Political Economy 103, no. 5:903-937.

Besley, Timothy, and Anne Case. 2003. Political Institutions and Policy Choices: Evidence from the United States. Journal of Economic Literature 41, no. 1:7-73.

Besley, T., and R. Burgess. 2004. Can labor regulation hinder economic performance? Evidence from India. Quarterly Journal of Economics 119, no. 1:91-134.

Biebuyck, Daniel, ed. 1963. African Agrarian Systems; Studies Presented and Discussed. Foreword by Daryll Forde.Oxford University Press. 
Binswanger, H., Deininger, K., and Feder, G. 1995. Handbook of Development Economics. In . Amsterdam: North-Holland.

Binswanger, H., and M. Rosenzweig. 1986. Behavioral and Material Determinants of Production Relations in Agriculture. Journal of Development Studies 22, 503-539.

Binswanger, Hans P., Deninger, Klaus, and Feder, Gershon. 1995. Power, Distortions, Revolt and Reform in Agricultural Land Relations. In Handbook of Development Economics, Volume III, edited by J. Behrman and T. N. Srinivasan. Amsterdam: Elselvier Science, B.V.

Bockstette, V., A. Chanda, and L. Putterman. 2002. States and Markets: The Advantage of an Early Start. Journal of Economic Growth 7, no. 4:347-369.

Broegaard, Rikke J., Heltberg, Rasmus, and Machlow-Moller, Nikolaj. 2002. Property Rights and Land Tenure Security in Nicaragua.Center for Economic and Business Research, Copenhagen.

Bromley, Daniel. 1989. Property Relations and Economic Development: The Other Land Reform. World Development 17, no. 6:867-877.

Brown, John, and Timothy Guinnane. 2005. Regions and Time in the European Fertility Transition: Problems in the Princeton Project's Statistical Methodology. Explorations in Economic History.

Bruce, J., and Migot-Adholla, S., eds. 1994. Searching for Land Tenure Security in Africa. Dubuque, IA: Kendall/Hunt.

Bruce, J., and Migot-Adholla, S. E., eds. 1994. Searching for Land Tenure Security in Africa. Iowa: Kendall/Hunt.

Burgess, R., and R. Pande. 2005. Do rural banks matter?: evidence from the Indian social banking experiment. American Economic Review 95, no. 3:780-795.

Carter, Michael R., and Olinto, Pedro. 2000. Getting Institutions 'Right' for Whom: Credit Constraints and the Impact of Property Rights on the Quantity and Composition of Investment.University of Wisconsin-Madison.

Cartier, Michael R., Wiebe, Kieth D., and Blarel, Benoit. 1994. Tenure Security for Whom? Differential Effects of Land Policy in Kenya. In Searching for Land Tenure Security in Africa, edited by John W. Bruce and Shem E. Migot-Adholla. Washington, DC: The World Bank.

Chattopadhyay, R., and E. Duflo. 2004. Women as policy makers: Evidence from a randomized policy experiment in India. Econometrica 72, no. 5:1409-1443.

Chauveau, Jean-Pierre. 2002. La Loi Ivoirienne de 1998 sur le Domaine Foncier Rural et L'agriculture de Plantation Villageoise: Une Mise en Perspective Historique et Sociologique. Land Reform: Land Settlement and Cooperativesno. 1:62-79. 
Chauveau, Jean-Pierre. 2000. Question Foncière et Construction Nationale en Côte d'Ivoire. Les Enjeux Silencieux d'un Coup d'Etat. Politique Africaine 17, 94-125.

Chavas, Jean-Paul, Ragan Petrie, and Michael Roth. 2005. Farm Household Production Efficiency: Evidence from the Gambia. American Journal of Agricultural Economics 87, no. 1:160-179.

Chemin, M. 2004. Does the Quality of the Judiciary Shape Economic Activity? Evidence from India. Ph.D. diss., London School of Economics.

Clague, C., P. Keefer, S. Knack, and M. Olson. 1999. Contract-Intensive Money: Contract Enforcement, Property Rights, and Economic Performance. Journal of Economic Growth 4, no. 2:185-211.

Côte d'Ivoire. 2003. Linas-Marcoussis Agreement.

Crook, Richard C. Civil War in Cote d'Ivoire; Behind the Headlines.

Curtin, P. D. 1989. Death by Migration: Europe's Encounter with the Tropical World in the 19th Century. New York: Cambridge University Press.

de Laiglesia, Juan R. 2004. Investment and Credit Effects of Land Titling and Registration: Evidence from Nicaragua.London School of Economics.

Demetriades, P. O., and K. B. Luintel. 2001. Financial restraints in the South Korean miracle. Journal of Development Economics 64, no. 2:459-479.

Deninger, Klaus, and Juan S. Chamorro. 2004. Investment and Equity Effects of Land Regularization: The Case of Nicaragua. American Journal of Agricultural Economics 30, 101-116.

Djankov, S., et al. 2003. The New Comparative Economics. Journal of Comparative Economics 31, no. 4:595-619.

Djankov, S., R. La Porta, F. Lopez-De-Silanes, and A. Shleifer. 2002. The Regulation of Entry. Quarterly Journal of Economics 117, no. 1:1-37.

Dowall, David E., and Michael Leaf. 1991. The Price of Land for Housing in Jakarta. Urban Studies 28, no. 5:707-722.

Duflo, E., and Banerjee, A. V. 2004. Do Firms Want to Borrow More? Testing Credit Constraints Using a Directed Lending Program.Massachusetts Institute of Technology.

Esfahani, H. S., and M. T. Ramirez. 2003. Institutions, Infrastructure, and Economic Growth. Journal of Development Economics 70, no. 2:443-477.

Feder, Gershon, and Tongroj Onchan. 1987. Land Ownership Security and Farm Investment in Thailand. American Journal of Agricultural Economics 69, no. 2:311-320. 
Field, Erica. 2003. Entitled to Work: Urban Property Rights and Labor Supply in Peru.Harvard University.

Field, Erica. 2003. Fertility Responses to Urban Land Titling Programs: The Roles of Ownership Security and the Distribution of Household Assets. Harvard University.

Field, Erica, and Torero, Maximo. 2004. Do Property Titles Increase Credit Access Among the Urban Poor? Evidence from a Nationwide Titling Program.Harvard University.

Firmin-Sellers, Kathryn. 1996. The Transformation of Property Rights in the Gold Coast : An Empirical Analysis Applying Rational Choice Theory. New York: Cambridge University Press.

Firmin-Sellers, Kathryn, and Patrick Sellers. 1999. Expected Failures and Unexpected Successes of Land Titling in Africa. World Development 27, no. 7:1115-1128.

Fisman, R. 2001. Estimating the value of political connections. American Economic Review 91, no. 4:10951102.

Fisman, R., and S. J. Wei. 2004. Tax rates and tax evasion: Evidence from "missing imports" in China. Journal of Political Economy 112, no. 2:471-496.

Foster, A. D., and Rosenzweig, M. R. 2001. Democratization, Decentralization and the Distribution of Local Public Goods in a Poor Rural Economy.University of Pennsylvania.

Francisco, Alcalá, and Antonio Ciccone. 2004. Trade and Productivity. Quarterly Journal of Economics 119, no. 2:613-646.

Frankel, J., and A. Rose. 2002. An Estimate of the Effect of Common Currencies on Trade and Income. Quarterly Journal of Economics 117, no. 2:437-466.

Frankel, J. A., and D. Romer. 1999. Does Trade Cause Growth? American Economic Review 89, no. 3:379399.

Fred-Mensah, B. K. 1996. Changes, Ambiguities and Conflicts in Buem, Eastern Ghana.Johns Hopkins University.

Freudenberger, Mark S. 2000. Tenure and Natural Resources in the Gambia: Summary of Research Findings and Policy Options. Vol. 40. University of Wisconsin-Madison: Land Tenure Center.

Friedman, Joseph, Emmanuel Jimenez, and Stephen K. Mayo. 1988. The Demand for Tenure Security in Developing Countries. Journal of Development Economics 29, 185-198.

Furth, Rebecca. 1998. Ivory Coast Country Profile. In Country Profiles of Land Tenure: Africa, 1996, edited by John W. Bruce. University of Wisconsin-Madison: Land Tenure Center.

Galiani, S., P. Gertler, and E. Schargrodsky. 2005. Water for life: The impact of the privatization of water services on child mortality. Journal of Political Economy 113, no. 1:83-120. 
Glaeser, E. L., R. La Porta, F. Lopez-de-Silanes, and A. Shleifer. 2004. Do Institutions Cause Growth? Journal of Economic Growth 9, no. 3:271-303.

Golan, Elise H. 1994. Land Tenure Reform in the Peanut Basin of Senegal. In Searching for Land Tenure Security in Africa, edited by John W. Bruce and Shem E. Migot-Adholla. Washington, DC: The World Bank.

Goldberg, P. K., and N. Pavcnik. 2003. The response of the informal sector to trade liberalization. Journal of Development Economics 72, no. 2:463-496.

Guerty, M. K., and Miguel, E. 2000. Community Participation and Social Sanctions in Kenyan Schools.Harvard University.

Hall, R. E., and C. I. Jones. 1999. Why Do Some Countries Produce So Much More Output per Worker than Others? Quarterly Journal of Economics 114, no. 1:83-116.

Hart, Terese B., and Robert Ducarme. 2005. Forestry and Conservation Activities During a War Fought over Land and Resources in the Democratic Republic of Congo. ETFRN News42-44.

Hayes, Joseph, Michael Roth, and Lydia Zepeda. 1997. Tenure Security, Investment and Productivity in Gambian Agriculture: A Generalized Probit Analysis. American Journal of Agricultural Economics 79, 369-382.

Heckman, James J., and Vytlacil, Edward J. 2000. Local Instrumental Variables. In Nonlinear Statistical Modeling: Essays in Honor of Takeshi Amemiya, edited by C. Hsiao, K. Morimune and J. Powell. Cambridge: Cambridge University.

Hill, Polly. 1963. The Migrant Cocoa-Farmers of Southern Ghana; A Study in Rural Capitalism. Cambridge Eng.: University Press.

Huggins, Chris, et al. 2005. Land, Conflict and Livelihoods in the Great Lakes Region: Testing Policies to the Limit. Vol. 14. Nairobi: African Center for Technology Studies.

Human Rights Watch. 2004. Côte d'Ivoire: Accountability for Serious Human Rights Crimes Key to Resolving Crisis.

Imbens, Guido, and Joshua Angrist. 1994. Identification and Estimation of Local Average Treatment Effects. Econometrica 62, no. 3:467-475.

Jansen, Kees, and Esther Roquas. 1998. Modernizing Insecurity; The Land Titling Project in Honduras. Development and Change 29, 81-106.

Jin, H. H., and Y. Y. Qian. 1998. Public versus private ownership of firms: Evidence from rural China. Quarterly Journal of Economics 113, no. 3:773-808. 
Johnson, Nancy L. 2001. Tierray Libertad: Will Tenure Reform Improve Productivity in Mexico's Ejido Agriculture? Economic Development and Cultural Change291-309.

Kan, K. 2000. Informal capital sources and household investment: evidence from Taiwan. Journal of Development Economics 62, no. 1:209-232.

Kasanga, Kasim, and Kosey, Nii A. 2001. Land Management in Ghana: Building on Tradition and Modernity. London: International Institute for Environment and Development.

Kaufmann, D., A. Kraay, and M. Mastruzzi. 2004. Governance Matters III: Governance Indicators for 1996, 1998, 2000, and 2002. World Bank Economic Review 18, no. 2:253-287.

Knack, S., and P. Keefer. 1997. Does Social Capital Have an Economic Payoff? A Cross-Country Investigation. Quarterly Journal of Economics 112, no. 4:1251-1288.

Knox, Anna. 1998. Gambia Country Profile. In Country Profiles of Land Tenure: Africa, 1996, edited by John W. Bruce. University of Wisconsin-Madison: Land Tenure Center.

Knox, Anna. 1998. Ghana Country Profile. In Country Profiles of Land Tenure: Africa, 1996, edited by John W. Bruce. University of Wisconsin-Madison: Land Tenure Center.

Kogel, T. 2005. Youth Dependency and Total Factor Productivity. Journal of Development Economics 76, no. 1:147-173.

Kone, Mariatou. 2002. Gaining Rights of Access to Land in West-Central Côte d'Ivoire. London: International Institute for Environment and Development.

La Ferrara, E. 2003. Kin Groups and Reciprocity: A Model of Credit Transactions in Ghana. American Economic Review 93, no. 5:1730-1751.

La Porta, R., F. Lopez-De-Silanes, A. Shleifer, and R. Vishny. 1999. The Quality of Government. Journal of Law Economics \& Organization 15, no. 1:222-279.

Lanjouw, Jean O., and Phillip I. Levy. 2002. Untitled: A Study of Formal and Informal Property Rights in Urban Equador. The Economic Journal986-1019.

Leisz, Steve. 1998. Zaire Country Profile. In Country Profiles of Land Tenure: Africa, 1996, edited by John W. Bruce. University of Wisconsin-Madison: Land Tenure Center.

Lopez, R. 1996. Land Titling and Investment in Honduras.Department of Agricultural and Resource Economics, University of Maryland, College Park, MD.

Mahama, Suleimana. 2003. The Ghana Land Administration Project: The Process and Challenges. Marburg, Germany: Philipps-University. 
Manning, Alan. 2004. Instrumental Variables for Binary Treatments with Heterogenous Treatment Effects: A Simple Exposition. Contributions to Economic Analysis \& Policy 3, no. 1:1273-1273.

Masters, W. A., and M. S. McMillan. 2001. Climate and Scale in Economic Growth. Journal of Economic Growth 6, no. 3:167-186.

Mauro, P. 1995. Corruption and Growth. Quarterly Journal of Economics 110, no. 3:681-712.

McEvedy, C., and Jones, R. 1978. Atlas of World Population History. New York: Facts on File.

Miceli, Thomas J., C. F. Sirmans, and Joseph Kieyah. 2001. The Demand for Land Title Registration: Theory with Evidence from Kenya. American Law and Economics Review 3, no. 2:275-287.

Migot-Adholla, Shem E., Place, Frank, and Oluch-Kosura, W. 1994. Security of Tenure and Land Productivity in Kenya. In Searching for Land Tenure Security in Africa, edited by John W. Bruce and Shem E. Migot-Adholla. Washington, DC: The World Bank.

Ministry of Lands and Forestry. 2003. Ghana: Emerging Land Tenure Issues.Accra, Ghana.

Moyroud, Celine, and Katunga, John. 2002. Coltan Exploration in Eastern Democratic Republic of the Congo (DRC). In Scarcity and Surfeit. Nairobi: African Centre for Technology Studies.

North, Douglass C. 1981. Structure and Change in Economic History. New York: Norton \& Co.

Pande, R. 2003. Can mandated political representation increase policy influence for disadvantaged minorities? Theory and evidence from India. American Economic Review 93, no. 4:1132-1151.

Pender, John L., and John M. Kerr. 1999. The Effects of Land Sales Restrictions: Evidence from South India. Agricultural Economics 21, 279-294.

Peters, Pauline E. 1994. Dividing the Commons: Politics, Policy, and Culture in Botswana. Charlottesville: University Press of Virginia.

Pinckney, Thomas C., and Peter K. Kimuyu. 1994. Land Tenure Reform in East Africa: Good, Bad or Unimportant? Journal of African Economies 3, no. 1:1-28.

Place, Frank, and Peter Hazell. 1993. Productivity Effects of Indigenous Tenure Systems in Sub-Saharan Africa. American Journal of Agricultural Economics 75, no. 1:10-19.

Place, Frank, and S. E. Migot-Adholla. 1998. The Economic Effects of Land Registration on Smallholder Farms in Kenya: Evidence from Nyeri and Kakamega Districts. Land Economics 74, no. 3:360-373.

Raynaut, Claude. 1997. Sahel Diversité et Dynamiques des Relations Société Nature. Edited by Claude Raynaut, Emmanuel Grégoire. London; New York: Routledge.

Rodrik, Dani. 1999. Democracies Pay Higher Wages. Quarterly Journal of Economics 114, no. 3:707-738. 
Rodrik, Dani, Arvind Subramanian, and Francesco Trebbi. 2004. Institutions Rule: The Primacy of Institutions Over Geography and Integration in Economic Development. Journal of Economic Growth 9, no. 2:131-165.

Roth, Michael, Cochrane, Jeffrey, and Kisamba-Mugerwa, W. 1994. Tenure Security, Credit Use, and Farm Investment in the Rujumbura Pilot Land Registration Scheme, Uganda. In Searching for Land Tenure Security in Africa, edited by John W. Bruce and Shem E. Migot-Adholla. Washington, DC: The World Bank.

Roth, Michael, Unruh, Jon, and Barrows, Richard. 1994. Land Registration, Tenure Security, Credit Use, and Investment in the Shebelle Region of Somalia. In Searching for Land Tenure Security in Africa, edited by John W. Bruce and Shem E. Migot-Adholla. Washington, DC: The World Bank.

Sachs, J. D., and A. Warner. 1995. Economic-Reform and the Process of Global Integration. Brookings Papers on Economic Activityno. 1:1-95.

Sullivan, M. J. 1991. Measuring Global Values. New York: Greenwood.

Taylor, C. L., and Hudson, M. C. 1972. World Handbook of Political and Social Indicators. Ann Arbor, MI: ICSPR.

The World Bank. 2005. 2005 World Development Indicators.Washington D.C.

Topalova, P. 2005. Trade Liberalization, Poverty, and Inequality: Evidence from Indian Districts.NBER.

Toure, Mahamane D. 2003. Rural Land Tenure and Sustainable Development in the Sahel and West Africa; Secure Land Tenure Problems in the Sahel and West Africa: Nine Years After PRAIA; Regional Summary Report. Bamako, Republic of Mali: Permanent Interstates Committee for Drought Control in the Sahel.

Udry, Christopher, and Goldstein, Markus. 2004. Gender, Power and Agricultural Investment in Ghana. New Haven, CT: Yale University.

USDA Foreign Agricultural Service. 2004. Cote d'Ivoire Solid Wood Products Annual, 2004. Vol. IV4013.

Visaria, S. 2005. Legal Reform and Loan Repayment: The Microeconomic Impact of Debt Recovery Tribunals in India. Ph.D. diss., Columbia University.

Vlassenroot, Koen, and Chris Huggins. 2004. Land, Migration and Conflict in Eastern D.R. Congo. EcoConflicts 3, no. 4:1-4.

Wily, Liz A., and Hammond, Daniel. 2001. Land Security and The Poor in Ghana: Is There a Way Forward? A Land Sector Scoping Study.UK Department for International Development. 
TABLE-1: Institutions and Growth: Literature Review

\begin{tabular}{cccc}
\hline \hline Article & Dependent variables & Institutions $^{\text {Key results }}{ }^{1}$ \\
& & Measures & Instrument \\
\hline CORE PAPERS
\end{tabular}

Acemoglu, Johnson \&Robinson (2001)

Hall\&Jones (1999) Log GDP per capita (1995)

Protection against expropriation risk ${ }^{1}$ (1985-1995)

Settler mortality ${ }^{1}$

Index of social infrastructure ${ }^{2}$ which combines:

Log output per worker ${ }^{1}$ (1988)

i. index of government antidiversion

policies $^{3}$

ii. index of country's openness ${ }^{4}$
I. Distance from equator ${ }^{2}$

II. English speakers ${ }^{3}$

III. European-language speakers ${ }^{4}$

IV. Predicted trade share ${ }^{5}$
One standard deviation (SD) increase in protection against expropriation risk (1.5) increases GDP per worker by $118 \%$ (OLS) and 309\% (IV) .

One SD increase in index of social infrastructure (0.25) increases output per worker by $128 \%$ (OLS) and 261\% (IV).

\section{Annual GDP per capita growth (1974-}

Knack\&Keefer 1989) I. ICRG index 5

(1995) II. Private investment/GDP (1974-1989) II. BERI index ${ }^{6}$ (all averages)

No IV estimates.

One SD increase in ICRG index (13.50) increases annual per capita income growth rate by 1.24 (OLS)

Dependent variables are classified in

five groups (data from 1990s):

I. Interference with private sector $\quad$ I. Ethnolinguistic fractionalization

LLSV (1999) II. Efficiency

III. Output of public goods

II. Legal origin

III. Religion

No IV estimates.

IV. Size of public sector

V. Political freedom
A French legal origin country (relative to others) has $42 \%$ more infant mortaliy (OLS)
I.GDP per capita growth (1960-1985)

Mauro (1995)
II. Investment/GDP (1960-1985)

III. Investment/GDP (1980-1985) (all averages)
I. Index of institutional efficiency ${ }^{7}$

II. Index of bureaucratic efficiency ${ }^{8}$
One SD increase in index of bureaucratic Ethnolinguistic fractionalization ${ }^{6}$ efficiency (2.16) increases average growth (1960) of GDP per capita by $0.6 \%$ (OLS) and $2.3 \%$ (IV)

\section{PAPERS CITING CORE PAPERS}

$\begin{array}{lll} & & \text { I. Current institutions: } \\ \begin{array}{l}\text { Acemoglu, } \\ \text { Johnson }\end{array} & \text { I. Log GDP per capita (1995) } & \text { i. protection against expropriation risk } \\ \text { \&Robinson } & \text { II. Urbanization }^{2} \text { (1995) } & \text { ii. executive constraints in } 1990^{9} \\ (2002) & & \text { II. Early institutions: } \\ & & \begin{array}{l}\text { i. executive constraints in } 1900 \\ \text { ii. initial executive constraints }\end{array}\end{array}$

I. Log GDP per capita (1995)

Acemoglu II. Av. investment/GDP (1990s)

\&Johnson

(2005)
One SD increase in expropriation risk (1.5) increases GDP per capita by $118 \%$ (IV), controlling for urbanization in 1500

\section{Contracting institutions:}

i. legal formalism ${ }^{11}$

III. Private credit/GDP (1998)

IV. Average stock market capitalization ${ }^{3}$ /GDP (1990-1995)
II. Property rights institutions:

i. executive constraints

ii. protection against expropriation risk
I. Settler mortality

II. Log of indigenous population density in $1500^{7}$

III. legal origin ${ }^{8}$

\section{Aghion,} Howitt\&MayerFoulkes (2005) Average growth rate of GDP per capita
(1960-1995) relative to the United States

I. Private credit $^{12}$

\section{Liquid liabilities ${ }^{13}$}

III. Bank assets ${ }^{14}$ IV. Commercial-central bank ${ }^{15}$

Alcala\&Ciccone Log GDP per capita (1995)
(2004) Index of institutional quality ${ }^{16}$
I. Settler mortality

II. European-language speakers III.Predicted trade share (AC) ${ }^{12}$
One SD increase in expropriation risk (1.47) and legal formalism (1.24, using "check measure") together increase GDP per capita by $189 \%$ (OLS) and 523\% (IV).
I. Legal origin

II. Settler mortality
One SD increase in private credit $(0.28)$ increases steady-state GDP by $21 \%$ in Belgium $^{2}$
One SD increase in index of institutional quality increases GDP per capita by $35 \%$ (IV) (controls include log real openness ${ }^{3}$ )
Bockstette, Chanda\& Putterman (2002)
I. Log output per worker (1988) II. Average GDP per capita growth (1960-1995)
I. Distance from equator

II. English speakers

I. Index of social infrastructure

II. ICRG index
III. European-language speakers IV. Log predicted trade share V. State antiquity ${ }^{9}$
One SD increase in index of social infrastructure $(0.25)$ increases output per worker by $126 \%$ (OLS) and 229\% (GMM IV) 


\begin{tabular}{|c|c|c|c|c|}
\hline \multirow[t]{2}{*}{ Article } & \multirow[t]{2}{*}{ Dependent variables } & \multicolumn{2}{|c|}{ Institutions } & \multirow[t]{2}{*}{ Key results $^{1}$} \\
\hline & & Measure & Instrument & \\
\hline $\begin{array}{l}\text { Clague, Keefer, } \\
\text { Knack\&Olson } \\
\text { (1999) }\end{array}$ & $\begin{array}{l}\text { I. Annual per capita GDP growth } \\
\text { (1970-1992) } \\
\text { II.Output per worker (1988) } \\
\text { III. Capital per worker (1988) } \\
\text { IV. Years schooling per worker (1985) } \\
\text { V.TFP (1988) }\end{array}$ & $\begin{array}{l}\text { I. Contract-intensive money }{ }^{17} \\
\text { II. ICRG index } \\
\text { III. BERI index }\end{array}$ & $\begin{array}{l}\text { I. Colonial origin }^{10} \\
\text { II. Ethnolinguistic homogeneity }\end{array}$ & $\begin{array}{l}\text { One SD increase in contract-intensive } \\
\text { money ( } 0.14 \text { ) increases growth by } 94.5 \\
\text { (OLS) and } 1.739 \text { (IV), controlling for log } \\
\text { GDP per capita in } 1970\end{array}$ \\
\hline $\begin{array}{l}\text { Djankov, La } \\
\text { Porta, Lopez-de- } \\
\text { Silanes\&Shleifer }\end{array}$ & $\begin{array}{l}\text { I. Deaths from (i)intestinal infection (ii) } \\
\text { accidental poisoning } \\
\text { II. Quality standards (no. ISO } 9000 \\
\text { certifications) } \\
\text { III. Water pollution } \\
\text { IV. Unofficial economy:(i) size/ GDP } \\
\text { (ii) employment } \\
\text { V. Product market competition }\end{array}$ & $\begin{array}{l}\text { Number of different procedures that a } \\
\text { start-up has to comply with in order to } \\
\text { obtain a legal status, i.e. to start operating } \\
\text { as a legal entity. }\end{array}$ & No IV estimates. & $\begin{array}{l}\text { One SD increase in number of procedures } \\
\text { (4.37) increases deaths from intestinal } \\
\text { infection by } 4.588 \% \text { (OLS), controlling } \\
\text { for log per capita GDP in } 1999\end{array}$ \\
\hline
\end{tabular}

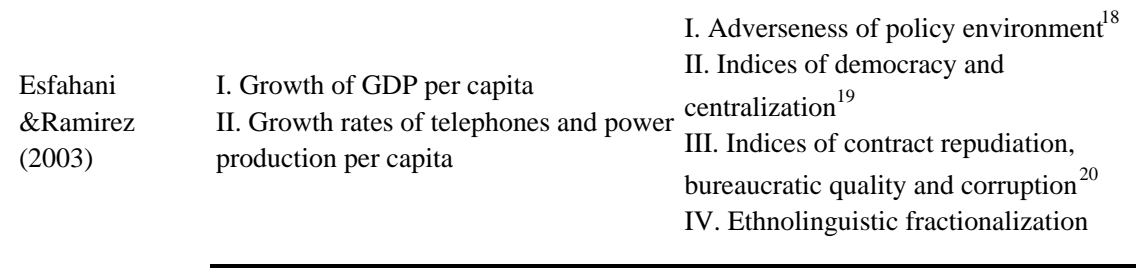

\begin{tabular}{lll}
\cline { 2 - 3 } & I. Log GDP per capita (2000) & \\
Glaeser, La & II. Growth rates of GDP per capita 1960- & I. Settler mortality \\
Porta, & 2000, overall and by decade & II. Legal origin \\
Lopez-de- & III. Years schooling & III. Log indigenous population \\
Silanes\&Shleifer & IV. Political institutions & density in 1500 \\
$(2004)$ & (III and IV are 5-year change) &
\end{tabular}
One SD increase in contract enforcemen No IV estimates. (0.24) increases GDP per capita growth by $5.8 \% \quad$ (OLS) (includes other institutional quality measures as controls)

One SD increase in constraints on executive (0.185) decreases GDP per capita by $6 \%$ (IV), controlling for population in temperate zone (1995) and years of schooling

\section{Change in annual growth rate of rea}

(2005) growth averages before and after leade deaths
Index of democratization $^{22} \quad$ No IV estimates.
Knack\&Keefer I. Average annual growth in per capita

(1997) income (1980-1992)

II. Investment/GDP (1980-1992)
I. Trust $^{23}$

II. Civic norms (civic cooperation)
I. Ethnolinguistic homogeneity

II. \% Law students 1963
One SD increase in democratization increases annual growth by $2.1 \%$ (OLS) after the deaths of leaders in autocratic regimes

One SD increase in trust (0.14) increases annual per capita income growth by $1.1 \%$ (OLS) and 1.2\% (IV) (includes other controls)
Annual average growth rate of TFP (1965-1990, panel data of 5-year averages)
Index of social infrastructure
I. English speakers

II. European-language speakers

III. Predicted trade shares

IV. Distance from equator V. State antiquity
One SD increase in index of social infrastructure (0.25) increases annual average TFP growth rate by $91.7 \%$ (IV), controlling for initial log TFP

\section{Masters} \&McMillan (2001)

Rodrik (1999) Average dolla
(1985-1989) Log output per worker (1988)

$\longrightarrow$

\section{Political institutions:}

i. two rule of law indicators ${ }^{24}$ ii. two democracy indicators ${ }^{25}$

II. Labor market institutions:

i. unionization rate ii. number ILO workers' rights conventions ratified
I. Distance from equator

II. Predicted trade share

III. English speakers

IV. European-language speakers in
One SD increase in index of social infrastructure (0.257) increases output per worker by $680 \%$ (IV) for "tropical" countries (average frostdays $<5$ per month winter)
I. Dummy for oil exporter

II. Colonial origins

III. Each measure of democracy

as an instrument for the other
One SD increase in freedom house index (0.33) increases average dollar wages in manufacturing by $19.8 \%$ (OLS) and $37.62 \%$ (IV) (includes controls)

\section{Rodrik, $\quad$ Same as Clague, Keefer, Knack\&Olson}

Subramanian (1999), except they use GDP per capita Rule of law index ${ }^{26}$

\&Trebbi (2004) (1995)

\section{Settler mortality \\ II. European-language speakers \\ III. Predicted trade shares}

One SD increase in rule of law index (0.94) increases GDP per capita by $112 \%$ (OLS) and 205\% (IV), controlling for distance from equator 
Notes on Outcome Variables:

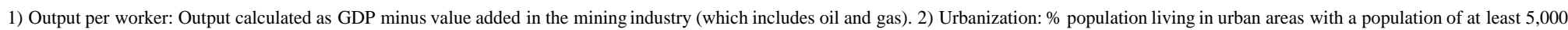

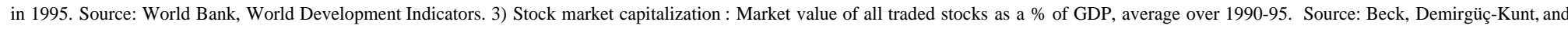
Levine(2003)

\section{Notes on Institution Measures:}

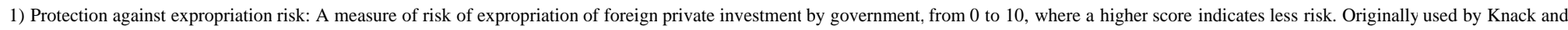
Keefer (1995). Source: IRIS Center, also known as Political Risk Services

2) Index of social infrastructure: Institutions and government policies that provide incentives for individuals and firms in an economy.

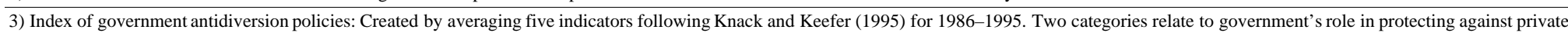

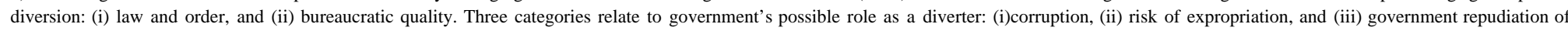
contracts. The index takes values from zero to one (higher is better). Source: Political Risk Services.

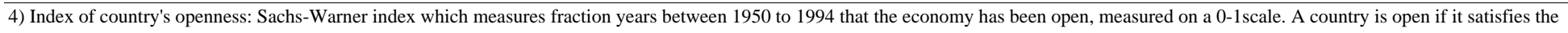

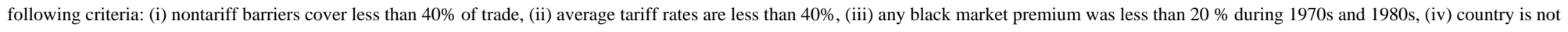
classified as socialist by Kornai (1992), and (v) government does not monopolize major exports. Source: Sachs andWarner (1995).

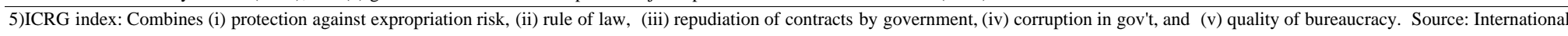
Country Risk Guide (ICRG) dataset, Political Risk Services.

6)BERI index: Combines (i)contract enforceability, (ii) infrastructure quality, (iii) nationalization potential, (iv) bureaucratic delays. (Business Environmental Risk Intelligence).

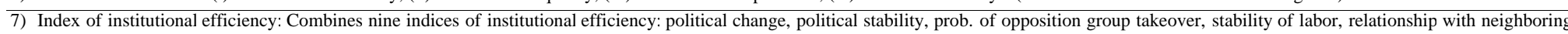

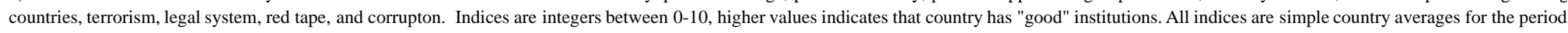
1980-1983. Source: Business International (BI), now part of Economist Intelligence Unit.

8) Index of bureaucratic efficiency: Combines three indices used for institutional efficiency measure: judiciary system, red tape and corruption indices.

9) Executive constraints : 1-7 category scale, higher score means more constraints on the executive. Equals one if country not independent. (Polity III data set, Gurr (1997))

10) Initial executive constraints: Executive constraints in the first year that country appears in the Gurr's (1997) Polity III data set. Source: Polity III data set, Gurr (1997)

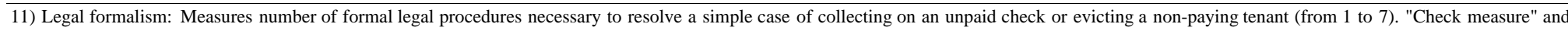
"Eviction measure" from Djankov, La Porta, Lopez-de-Silanes, and Shleifer (2003). Source: Djankov, La Porta, Lopez-de-Silanes, and Shleifer (2002, 2003).

12) Private credit: Value of credits by financial intermediaries to the private sector, divided by GDP.

13) Liquid liabilities: Currency plus demand and interestbearing liabilities of banks and nonbank financial intermediaries, divided by GDP

14) Bank Assets: Ratio of all credits by banks (but not other financial intermediaries) to GDP

15) Commercial-central bank: Ratio of commercial bank assets to the sum of commercial plus central bank assets, which has been used by others.

16) Institutional Quality: Combines bureaucratic quality, law/order, and property rights protection indices. (Political Risk Services; similar to Knack-Keefer (1995), Hall- Jones (1999).

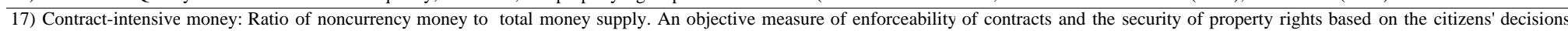
regarding the form in which they choose to hold their financial assets.

18) Adverseness of policy environment: Measured by black market premium on the foreign exchange rate. (Barro and Lee (1994))

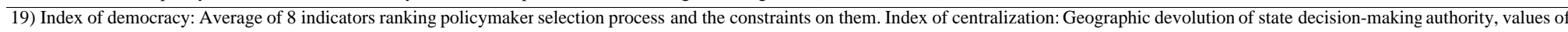
1 and 3 assigned to federal and unitary systems, respectively, and 2 to intermediate categories. (Polity III data set, Jaggers and Gurr's (1996)).

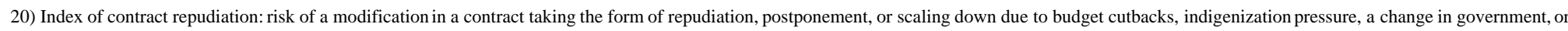

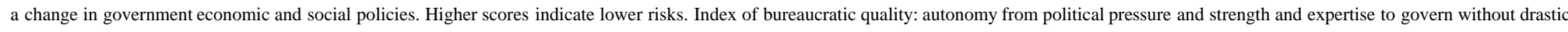

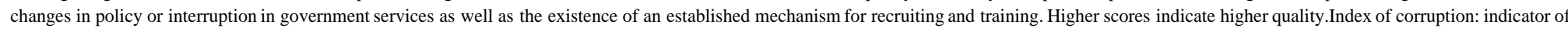

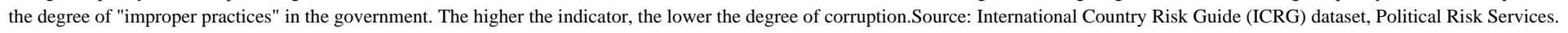

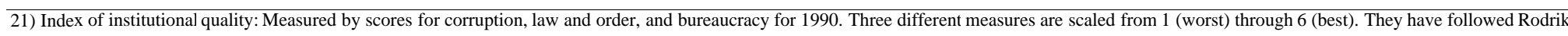
in employing a rescaled unweighted average of the three measures. Source: International Country Risk Guide (ICRG) dataset, Political Risk Services.

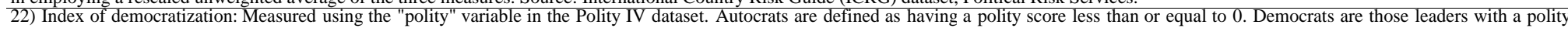
score greater than 0 .

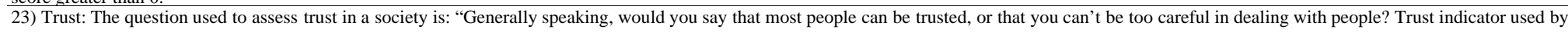
the authors is the percentage of respondents in each nation replying "most people can be trusted” (after deleting the "don’t know” responses).

24) These indicators are: (i) ICRG (Knack\&Keefer(1995)) (ii) bureaucratic efficiency (Mauro (1995))

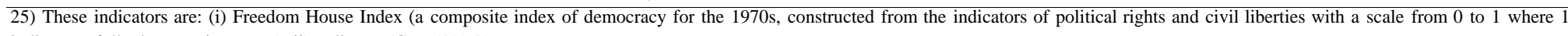
indicates a fully democratic system) (ii) Polity III (Gurr (1995))

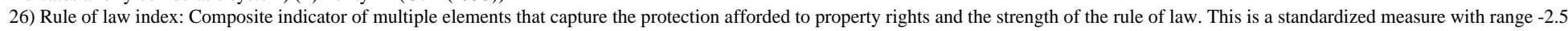
(weakest institutions) and 2.5 (strongest institutions). Approximates for 1990's institutions. Source: Kaufmann, Kraay, and Zoido-Lobaton (2002)

\section{Notes on Instruments:}

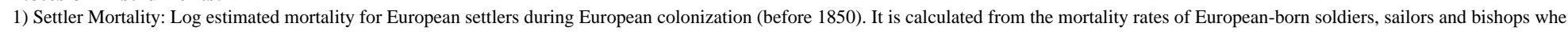
stationed in colonies. It measures the effects of local diseases on people without inherited or acquired immunities. Source: Curtin (1989).

2) Distance from equator: Center of county or province within a country that contains the most people. Source:Global Demography Project, University of California, Santa Barbara.

3) English speakers: Fraction of the population speaking English at birth.

4) European-language speakers: Fraction of the population speaking one of the five principal languages of Europe (English, French, German, Portuguese, or Spanish) at birth.

5) Predicted trade share: Log value, based on a gravity trade model that only uses a country's population and geographical features. Source: Frankel and Romer (1999).

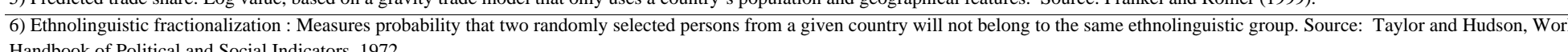

Handbook of Political and Social Indicators, 1972

7) Indigenous population density: Population density is calculated as total population divided by land area usable for agriculture. Source: McEvedy and Jones (1978).

8) Legal Origin: Legal origin of the company law or commercial code of each country (French Commercial Code versus English Common Law Origin) Source: La Porta et al (1999).

9) State antiquity: Index for the depth of experience with state-level institutions . Scales from zero to one.

10) Colonial Origin: Dummy variable indicating whether country was a British, French, German, Spanish, Italian, Belgian, Dutch or Portuguese colony. Source: La Porta et al (1999'.

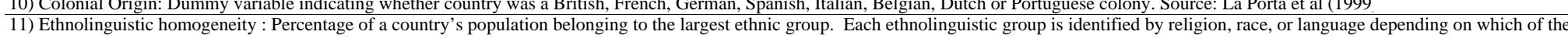
appears to be the most important cleavage in the given community. Source: Sullivan (1991).

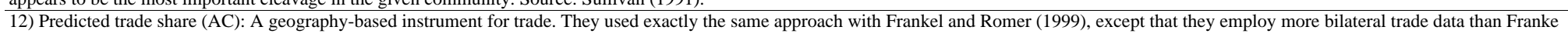
and Romer (1999).

Notes on Key Results:

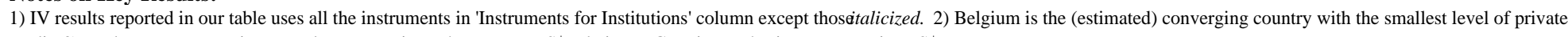
credit. 3) Real openness: Log imports plus exports in exchange rate US\$ relative to GDP in purchasing-powerparity US\$. 


\begin{tabular}{|c|c|c|c|c|c|}
\hline & $\begin{array}{c}\text { Base Sample } \\
\text { (1) }\end{array}$ & $\begin{array}{l}\text { Base Sample } \\
\text { without OECD } \\
\text { countries } \\
\text { (2) }\end{array}$ & $\begin{array}{c}\text { Base Sample } \\
\text { (3) }\end{array}$ & $\begin{array}{l}\text { Base Sample } \\
\text { without OECD } \\
\text { countries } \\
\text { (4) }\end{array}$ & $\begin{array}{c}\text { AJR Base Sample } \\
\text { (5) }\end{array}$ \\
\hline \multicolumn{6}{|c|}{ Panel A: Ordinary Least Squares (Dependent Variable: Median Headcount Ratio) } \\
\hline \multicolumn{6}{|c|}{ Protection against expropriation risk } \\
\hline \multirow[t]{2}{*}{$(1985-1995)$} & -9.99 & -12.61 & -8.65 & -11.14 & \\
\hline & $(1.78)$ & $(2.48)$ & $(2.14)$ & $(2.32)$ & \\
\hline \multirow[t]{2}{*}{ Distance from equator } & & & -7.21 & -36.32 & \\
\hline & & & (20.16) & (23.38) & \\
\hline \multirow[t]{2}{*}{ Asia dummy } & & & 11.82 & -14.76 & \\
\hline & & & $(7.14)$ & $(7.01)$ & \\
\hline \multirow[t]{2}{*}{ Africa dummy } & & & 16.52 & 17.26 & \\
\hline & & & (5.53) & (5.36) & \\
\hline \multirow[t]{2}{*}{ Other continent dummy } & & & 13.81 & & \\
\hline & & & (13.24) & & \\
\hline
\end{tabular}

Panel B: Two-Stage Least Squares (Dependent Variable: Median Headcount Ratio)

Protection against expropriation risk

\begin{tabular}{|c|c|c|c|c|}
\hline (1985-1995) & $\begin{array}{r}-18.30 \\
(3.95)\end{array}$ & $\begin{array}{r}-19.88 \\
(7.54)\end{array}$ & $\begin{array}{l}-32.79 \\
(18.92)\end{array}$ & $\begin{array}{l}-44.82 \\
(31.29)\end{array}$ \\
\hline Distance from equator & & & $\begin{array}{c}79.71 \\
(77.87)\end{array}$ & $\begin{array}{c}-9.02 \\
(64.68)\end{array}$ \\
\hline Asia dummy & & & $\begin{array}{c}14.79 \\
(14.62)\end{array}$ & $\begin{array}{c}26.10 \\
(20.67)\end{array}$ \\
\hline Africa dummy & & & $\begin{array}{c}-1.41 \\
(17.68)\end{array}$ & $\begin{array}{c}-0.64 \\
(21.31)\end{array}$ \\
\hline Other continent dummy & & & $\begin{array}{c}64.59 \\
(47.10)\end{array}$ & \\
\hline
\end{tabular}

Panel C: First Stage (Dependent Varibale: Protection Against Expropriation Risk (1985-1995))

\begin{tabular}{|c|c|c|c|c|c|}
\hline Log settler mortality & $\begin{array}{l}-0.59 \\
(0.13)\end{array}$ & $\begin{array}{l}-0.30 \\
(0.13)\end{array}$ & $\begin{array}{c}-0.27 \\
(0.18)\end{array}$ & $\begin{array}{l}-0.20 \\
(0.17)\end{array}$ & $\begin{array}{c}-0.34 \\
(0.18)\end{array}$ \\
\hline Distance from equator & & & $\begin{array}{c}2.77 \\
(1.42)\end{array}$ & $\begin{array}{c}0.29 \\
(1.65)\end{array}$ & $\begin{array}{c}2.00 \\
(1.38)\end{array}$ \\
\hline Asia dummy & & & $\begin{array}{c}0.07 \\
(0.50)\end{array}$ & $\begin{array}{c}0.28 \\
(0.47)\end{array}$ & $\begin{array}{c}0.46 \\
(0.50)\end{array}$ \\
\hline Africa dummy & & & $\begin{array}{c}-0.39 \\
(0.44)\end{array}$ & $\begin{array}{l}-0.28 \\
(0.41)\end{array}$ & $\begin{array}{c}-0.25 \\
(0.40)\end{array}$ \\
\hline Other continent dummy & & & $\begin{array}{c}1.67 \\
(0.95)\end{array}$ & & $\begin{array}{c}1.04 \\
(0.84)\end{array}$ \\
\hline$R^{2}$ & 0.30 & 0.10 & 0.42 & 0.13 & 0.33 \\
\hline Number of observations & 47 & 43 & 47 & 43 & 64 \\
\hline Percentiles of median headcount ratio & $\begin{array}{c}1 \% \\
0.28\end{array}$ & $\begin{array}{l}25 \% \\
5.56\end{array}$ & $\begin{array}{c}50 \% \\
18.94\end{array}$ & $\begin{array}{c}75 \% \\
36.45\end{array}$ & $\begin{array}{c}99 \% \\
87.60\end{array}$ \\
\hline
\end{tabular}

Notes: The dependent variable is the median headcount index (1981-2001) given by \% population living in households with consumption or income per person below the poverty line, defined as living on \$1 a day (\$32.74 per month at 1993 PPP), from Povcal Net, World Bank. Protection against expropriation risk (1985-1995) is the risk of expropriation of private investment by government, scaled from 0 to 10 , where a lower score means more risk, from Acemoglu, Johnson, and Robinson (2001). Panel A reports OLS estimates. Panel B reports two stage least square estimates, where we instrument for protection against expropriation risk using log European settler mortality, which is log of estimated mortality for European settlers during the early period of European colonization (before 1850), from Acemoglu, Johnson, and Robinson (2001). In Panel C, we report the corresponding first stage. In columns (3) and (4) where we include continent dummies as controls, the dummy for America is omitted, following Acemoglu, Johnson, and Robinson (2001). Standard errors are given in parentheses.

Our base sample is limited to 47 countries which were excolonies and for which we have headcount, expropriation risk and settler mortality data. To create the sample, we set the median headcount value to zero for four OECD countries which were excolonies: Australia, Canada, New Zealand, and USA assuming there is no one living under $\$ 1$ poverty line in these countries. AJR base sample in column (5) refers the largest sample of ex-colonies used by Acemoglu, Johnson, and Robinson (2001). 


\begin{tabular}{|c|c|c|c|c|}
\hline & The Gambia & Ivory Coast & Ghana & 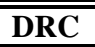 \\
\hline \multicolumn{5}{|c|}{ Coding of Institutions } \\
\hline $\begin{array}{l}\text { Expropriation } \\
\text { Risk }\end{array}$ & 8.27 & 7.00 & 6.27 & 3.50 \\
\hline Legal Origin & English & French & English & French \\
\hline Urbanization & $26 \%$ & $46 \%$ & $44 \%$ & $30 \%$ \\
\hline
\end{tabular}

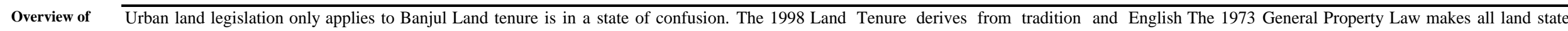

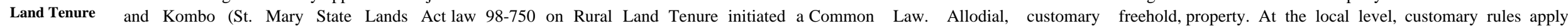
(1990)). Under this, land is state-owned transition to private ownership, but tenure issues common law freehold, leasehold and customary where state power is weak; less than $1 \%$ of land in the except if held in "fee simple" or subject to have become linked with political upheavals since tenancy are recognized. The 1986 Land Titling DRC is registered. In much of the country the grants. Customary land occupiers hold a 99 the early 1990s. Critically, more than a third of Registration Law applies only in a few urban areas. dominant factor in determining access to land has year renewable lease. The Lands (Provinces) the population consists of foreigners, and most Most of the country is governed by a mix of been war, which has brought armed occupation and Act 1946, which recognizes customary law conflict is over the status of both Ivorian and non- customary rules and legislation (e.g. the 1992 population displacement. holds elsewhere else, and district tribunals Ivorian migrants. constitution and the 1962 State Lands Act).

may apply Islamic law.

\section{Customary Sector}

\section{Extent}

99\% (i.e.outside Banjul \& Kombo)

$98 \%$ of land

80-90\% of Ghanaian land

97\% of land ( de facto)

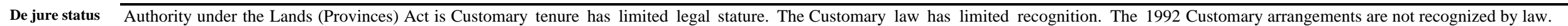
given to the District Authorities, who are the 1998 land law allows only the state, public Constitution recognizes chiefs' authority over stool head chiefs (seyfos) under 1990 Laws of the institutions and native Ivorians to own rural land. and skin lands, and of families over family lands. Gambia. District Tribunals may administer Though intended to create individual tenure, it Several laws, including article the 1992 Constitution customary and Islamic law, so long as these makes customary rights the basis of claims. (giving Land Commissions a veto over land are not "repugnant to justice." Communities registered as village cooperatives or transactions) and the 1994 Office of the associations have had their rights upheld by the Administrator of Stools Land Act circumscribe courts.

chiefs authority.

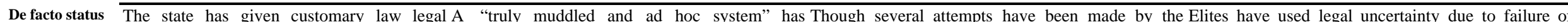
legitimacy. resulted from combined assertion of government government to centralize control over land, for the 1973 presidential decree to secure customary tenure to contol and tolerance of customary systems. most part they defer to customary authorities. Though a 1962 law vests all land in the state, the appropriate untitled land. Though required to president refused to enact a 1963 law that advertise lease of 'vacant' land, the state has allowed abolished customary tenure.

Bamis (local chiefs) to retain their leasing powers in return for political support. Local people, through chiefs and elders, have "de facto veto over the acquisition process" and "droit de regard" - an informal management right.

Gambian customary tenure is complex and There are over 20 ethnic groups. The Agni and There are broad regional differences between the There are over 250 ethnic groups spread across the diverse; a community may have multiple Baoule in central and eastern provinces are southern coast scrubland, the cocoa-growing central and northern rainforests, the northern and types of property regimes, and these will matrilineal. The king allocates land to lineages. rainforest of the southern interior, and northern southern savannahs, and the eastern Rift Valley change over time. Where all parties to a The Agni redistribute land annually, whereas the savannah. Ethnic differences also exist. Among the highlands. Population is concentrated in areas such as dispute are Muslim, District Tribunals may Baoule keep the same parcels of land over several Ashanti, Dagomba and Gonja, paramount chiefs the Kinshasa region, Banundu, and the Kivus. Other apply Islamic law. Approximately $90 \%$ of the years. Among matrilineal Senoufu, Lobi and have ultimate authority over land. "Traditional" areas are sparsely inhabited. Strictness of a tenure country is Muslim, and the Mandinka Fula, Koulango, the senior male of the founding lineage tenure systems have survived more in the relatively regime increases with population density (particularly Wolof, Jola and Serahuli account for more allocates land; in patrilineal Malinke the senior land abundant North. in Kivu, Bas-Congo, and near cities) 


\section{The Gambia}

Original village settlement (unless trumped by individuals. Allocation practices vary, but for the stools and skins, Tendamba (original settlers) and but cannot sell it, since the land "belongs" to the conquest). The male household head allocates most part land is allocated by a king, lineage clans own customary land. Ideologically, a central government. Where there is a strong land within the family and mediates land head, or senior male. community and its ancestors own the land. Allodial chieftancy (especially in the East), the Mwami (king) disputes. The seyfo (head chief) holds the land in trust for the community. There is some confusion about the relative powers of seyfos, alkalos (village chiefs), families and lineages which dates back to at least the early title is the highest proprietary interest (analogous to owns the land, and distributes it "through a freehold interest in English common law). It is sophisticated system of reward and punishment.” This invested in chiefs on behalf of their subjects in stool connects land to political power. Individual families and skin areas. In some areas tendamba and chiefs may directly control family land, and individuals assert competing claims to this title. Whether family often own trees. Customary authorities' power is colonial era. and stool/skin lands face the same regulations particularly great where rebel authorities are seen as remains ambiguous. illegitimate.

Right to

Transfer

Land

Inheritance

Land sales are generally restricted; extended Sales are common, though the seller may retain Land sales are restricted and require chiefs' or elders' Sales of land are generally restricted; customary families "own" cultivated land (including some use rights and have to approve any resale. permission. Non-transferable allodial title reside in tenure usually involves inalienable group land rights. fallow land), but cannot alienate it. Founding Local communities have developed their own the community and freeholds cannot be granted A community cannot sell land, but can cede it to other families have usufruct rights, and can transfer contracts, often recorded in writing as "petits from stool and skin lands. The Lands Commission villages or rent it to strangers. In Masisi, after land by inheritance, gifts, trades and loans. papiers" and endorsed by several "headmen and must approve land grants to outsiders. Customary promulgation of the 1973 law it became impossible to Some private property exists in the customary sub-prefects, and even some judges.” The state freehold is secure and transferable, but cannot be buy or sell land without the permission of the Hunde sector. Trees and wells are usually planters' system is of no use, since ownership can only be acquired by non-Ghanaians. An allodial title holder chiefs; this encouraged clientelism as they profited private property. Lineage and household established by a certificate that does not yet exist. can sell or gift a common law freehold and grant from selling large parcels. heads often exercise significant control over Conflicts have erupted between purchasers and leaseholds. Land can be purchased or gifted, but land transfers. Alienation outside the lineage return migrants who have claimed that the land is community leaders must agree if it is to an outsider is usually disallowed (less effective around inalienable. Banjul). Most primary rights transfers are Leaseholders can grant lesser rights (e.g.abusa and through inheritance. abunu sharecropping). The land market is informal, most transactions are unrecorded, and those documented are rarely noted by the state. settlement or direct allocation, include patrilineal systems, were outlawed, but this is not areas and patrilineal in the north, and among the matrilineal, while the Zande Vungara are patrilineal. permanent occupation, control of land use, usually enforced. Children of immigrants do not Volta and Ga. The matrilineal system is flexible, and inheritance without interference; this is have established inheritance rights. A tenant who allowing for a variety of possible heirs and ways to similar to western ownership. Women borrow selects an heir without his tuteur's permission inherit land. Patrilineal areas in the south suffer land from their husbands to cultivate may lose his rights. Women inherit nothing from from fragmentation into parcels too small to be vegetables and rice, though some own land husbands but have recently gained the right to economically viable. that is passed from mother to daughter. 
User Rights Owners can reclaim borrowed land in land Women can usually only access land through Chiefs can grant lesser interests to members of the Individual rights to the harvest are usually protected. scarce areas. Use rights (rights to build a their husbands. A mix of contracts exist that can community. These are typically customary freehold, Women may only have access to land through men plant fruit trees) are more common than to rights; these include tutorat, busan, bugnon, is indefinite so long as the land is not abandoned. Many squatters arrived from Rwanda and the rest of rent or lend out land. Those who sell land troukatalan, rental, surveillance or guardianship,

usually have all other land rights. Primary and pledging.

right holders can grant "secondary" rights (usually exclude ability to plant trees).

Pastures, mangroves, streams and most

forests are commons available for hunting and gathering. Common-property regimes are frequent, but not open access ones. Alkololu (local chiefs) and seyfolu (head chiefs) can determine a tongo - a seasonal prohibition on activities such as harvesting mangoes.

Right to

Improve

Land

Rights of

Non-

Community

Members
Women and borrowers have fewer land rights Individuals can lose land, but retain ownership The Regional Lands Commission must approve any State policy under Mobutu demanded obligatory than owners; they cannot plant trees or must over any trees they have planted. In the case of "development or disposition" of stool or skin lands. production of certain crops, contributing to food receive permission (because these are coffee and cocoa trees, this has been a source of Families are reluctant to tie up capital in orchard insecurity. Often poor land is used for this, causing associated with permanent rights). conflict.

Improvement rights are stronger for durable

improvements. A long-term borrower attempts to strengthen his or her rights by investing in wells, trees or fencing can spark conflict with the landowner. the DRC, setting up on ranches from 1999-2003.

With the return of the original land-owners, some have been evicted, while others have stayed under the protection of armed groups.

Land is often lent, usually on a seasonal basis Relations between indigenous cultivators and Strangers (non-subjects) must obtain the chief's Strangers have insecure tenure, or none at all. In the but sometimes longer, to settlers from other migrants are the most important aspect of Ivorian permission to reside in an area. After this is granted, some areas of the Kivus, Rwandan Hutu prisoners are ethnic groups. Payments may be symbolic or tenure. The 1998 law bars non-Ivorians from he acquires land from a landowner or the chief, for used as forced laborers. Congolese have been forced actual tribute, depending on land scarcity. owning rural land. Non-Ivorian farmers can at example as an "abusa" or "abunu" sharecropper. into camps, while Rwandan settlers are brought in to Incomers acquire land from chiefs or best hope for a long-term lease from the Abusa has also come to be used by local landless to take their land. founding families. Secondary rights are certificate-holder or the state. The Houphouët- acquire land. In forest areas, migrants are often in

transferred through borrowing, pledging, Boigny government encouraged migrants, who the majority. Here, chiefs act as landlords. Tenancy rental, and sharecropping. District tribunal obtained land mainly through "tutorat," whereby is less common in the North, as land is more members may grant land to newcomers, in one remits a debt of gratitude and continuing abundant, and migrants may obtain land for free.

contravention of Lands (Provinces) Act's regular payments to a local patron or "tuteur".

vesting of power in District Authorities. Foreigners, especially the Burkinabe, have been

Individuals tend to believe that authorities particularly vulnerable under the 1998 law.

only have this power if they gain lineage

consent. 


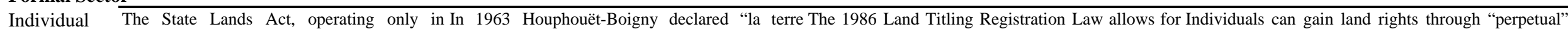

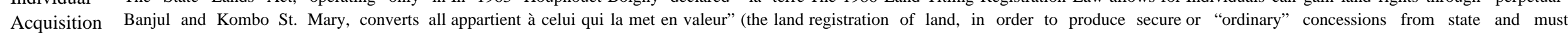
customary tenure into 99 year leases if the belongs to those who develop it). This has since tenure and reduce fraud in sale. This applies only in improve land during lease. This "mise en valeur" occupant applies for a title by a specified changed -- in 2001, one minister declared that Accra, Tema, and Kumasi and is generally principle implies a concession can be sold or deadline; if he does not, he becomes a tenant land belongs to the owner, not the farmer. Under inaccessible to peasants. Squatter rights are not bequeathed, but the state is the proprietor and can that can be evicted by the state. the 1998 law, land holders must obtain a land recognized by law. Though public land is officially revoke the concession if the parcel is abandoned, not certificate within 10 years, and after another 3 available to all Ghanaians, getting a land lease is improved, or transferred without approval. Only a years individual registration and private property time-consuming and expensive, so political and Congolese can have a perpetual concession. The will be enforced. Only 12 hectares can be economic elites have benefitted most. concessionaire pays a license fee or rent and individually owned; the rest comes in a 25 year lease from the state, which may be sold, mortgaged, inherited, and renewed. The length and expense of the process implies most land remains under community-based tenure. effectively occupies the land for many years. All children (born in and out of wedlock) must divide equally three quarters of the deceased's estate as inheritance. Land rights cannot be transmitted through death without a judge's approval.

State

Acquisition

and

involvement

The 1994 coup of Yayeh Jammeh mantained The 1998 law vests all unregistered land in the "Public land" categories in Ghana are (i) land The 1973 General Property Law made all lands, the status quo on tenure issues. All land not state. Though a 1962 law asserted state ownership compulsorily acquired (under the 1962 State Lands including forest resources, state property. Edict 81 in freehold in Banjul and Kombo St. Mary is over all land, the government allowed farmers to Act), and (ii) land invested in the president (1962 013 of 1981 and Constitution Article 10 make the vested in the state, as are resources such as retain land used in production. Government Administration of Lands Act). The State Lands Act under-soil, including mineral and petroleum wealth, forests, watercourses and expropriated land attempts to delineate mining, forest and tourist allows the state to acquire any land "in the public state property. The Mobutu "kleptocracy" (State Lands Act, 1990). The Land lands have been ineffective. Politicization of the interest.” Outstanding compensation claims on the encouraged land tenure "informalization” which Acquisition Act permits government land question has become part of the larger government are more than \$100 million USD, with allowed favored groups and individuals to expropriate appropriation of land for a broad range of politics of Ivorianness. some claims dating back to the 1970s. "public purposes," including defense,

conservation, and planning. land. The political deadlock between Mobutu and parliament in the early 1990s prevented legal redress to resolve the agricultural crisis or land-related issues.

\section{The Role of N/A \\ War During \\ the 1990s}

The 1998 law 98750 on Rural Land Tenure has N/A not been effectively enacted. Article IV of the Linas-Marcoussis Agreement (2003) reaffirms this law and charges the Government of National Reconciliation with implementation. The Accra III agreement of July 2004 specified changes to land tenure laws in the Linas-Marcoussis Agreement were to be implemented by August 2004. This deadline was not met.
Land conflict between Hema and Lendu in Ituri has a long history. 'Zairianisation' involved transferring several foreign concessions to Hema, and conflicts over these concessions are frequent. Violence since 1999 has displaced half a million people from Ituri, killed 50,000 and caused the state to lose control of several areas. Forced migration, crop theft by armed forces, and short-run gains to mining coltan, gold and diamonds led many to abandon food production. Illegal resource exploitation by foreign armed groups has affected locals' land access.

Sources: Toure, 2003; Knox, 1998; Chavas, Petrie Sources: Chauveau, 2000; Chauveau, 2002; Furth, 1998;

and Roth, 2005; Freudenberger, 2000. (Urbanization Conte, 2004; Crook, no date; Human Rights Watch, 2004; Sources: Toure, 2003; Wily and Hammond, 2001; Kasanga Sources: Huggins et al., 2005; Leisz, 1998; Aide et Action data from 2005 World Population Data Sheet, Risk Linas-Marcoussis Agreement, 2003; USDA Foreign and Kosey, 2001; Asiama, 2003; Ministry of Lands and Pour la Paix, 2004; African Development Fund, 2004; Hart and of Expropriation from Acemoglu, Johnson and Agricultural Service, 2004, Koné, 2002. (Urbanization Forestry, Ghana, 2003; Amanor, 1999; Mahama, 2003, Ducarme, 2005; Vlassenroot and Huggins, 2004; Moyroud and of Expropriation from Acemoglu, Johnson and Agricultural Service, 2004, Koné, 2002. (Urbanization Knox, 1998. (Urbanization data from 2005 World Population Katunga, 2002. (Urbanization data from 2005 World Robinson, 2001, originally from the IRIS-3 dataset, data from 2005 World Population Data Sheet, Risk of Data Sheet, Risk of Expropriation from Acemoglu, Johnson Population Data Sheet, Risk of Expropriation from Acemoglu, legal origin from The International Institute for Expropriation from Acemoglu, Johnson and Robinson, and Robinson, 2001, originally from the IRIS-3 dataset, and Johnson and Robinson, 2001, originally from the IRIS-3 Corporate Governance at the Yale School of 2001, originally from the IRIS-3 dataset, and legal origin legal origin from The International Institute for Corporate dataset, and legal origin from The International Institute for
Management, and ethnic and religious data from the from The International Institute for Corporate Governance
Governance at the Yale School of Management) Corporate Governance at the Yale School of Management) 
TABLE-4: Institutions and Development: Within Country Evidence

\begin{tabular}{|c|c|c|c|}
\hline \multirow{2}{*}{$\begin{array}{c}\text { Institutions in Cross- } \\
\text { country literature } \\
\end{array}$} & \multicolumn{2}{|r|}{ Within Country Counterpart } & \multirow{2}{*}{ Findings -- an illustration } \\
\hline & Country & Institution Measure (Paper) & \\
\hline \multirow{2}{*}{$\begin{array}{l}\text { Protection against } \\
\text { expropriation risk; Index } \\
\text { of Government } \\
\text { Antidiversion policies; } \\
\text { ICRG Index }\end{array}$} & Indonesia & Political Connections (Fisman) & \multirow{2}{*}{$\begin{array}{l}\text { Fisman exploits differences in share price reactions to } \\
\text { news about former President Suharto's health of firms } \\
\text { with varying degrees of political exposure to show that } \\
\text { political connections can account for upto a quarter of a } \\
\text { firm's share price. }\end{array}$} \\
\hline & $\begin{array}{l}\text { China (importer) } \\
\text { Hongkong } \\
\text { (exporter) }\end{array}$ & $\begin{array}{l}\text { Evasion Gap: Difference between reported } \\
\text { exports to a country and imports reported by } \\
\text { receiving country (Fisman and Wei) }\end{array}$ & \\
\hline \multirow{2}{*}{ Index of country openness } & India & Tariff changes (Topalova) & \multirow{2}{*}{$\begin{array}{l}\text { Topalova uses variations in exposure of Indian districts } \\
\text { to trade liberalization to show that districts whcih } \\
\text { witnessed the largest reductions in trade protectionism } \\
\text { saw the least fall in poverty. }\end{array}$} \\
\hline & $\begin{array}{l}\text { Colombia } \\
\text { Brazil }\end{array}$ & Tariff changes (Pavcnik and Goldberg) & \\
\hline $\begin{array}{l}\text { Intellectual Property } \\
\text { Rights }\end{array}$ & India & $\begin{array}{l}\text { Assessment of patent protection (Chaudhuri, } \\
\text { Goldberg and Jia) }\end{array}$ & $\begin{array}{l}\text { Without price regulation or compulsory licensing, total } \\
\text { annual welfare losses to the Indian economy from } \\
\text { withdrawal of } 4 \text { domestic product groups in the } \\
\text { fluoroquinolone sub-segment would be about } 118 \% \text { of } \\
\text { the entire sales of the systemic anti-bacterials segment of } \\
\text { pharmaceuticals in } 2000 \text {. }\end{array}$ \\
\hline $\begin{array}{l}\text { Legal Formalism; Contract } \\
\text { Repudiation }\end{array}$ & India & $\begin{array}{l}\text { Debt Relief Tribunal (Visaria) } \\
\text { State court efficiency (Chemin) }\end{array}$ & $\begin{array}{l}\text { Visaria exploits variation in spread of debt tribunals, and } \\
\text { in which firms were affected by it, to shows that tribunal } \\
\text { establishment reduced loan repayment delinquency in } \\
\text { loan by 3-10 percent. }\end{array}$ \\
\hline \multirow{2}{*}{ Privatization } & Argentina & $\begin{array}{l}\text { Privatization of water services } \\
\text { (Galiani, Gertler, and Schargrodsky) }\end{array}$ & \multirow{2}{*}{$\begin{array}{l}\text { Galiani, Gertler, and Schargrodsky exploit time-series } \\
\text { variation in the privatization of water servies across } \\
\text { - Argentinian municipalities to show that water } \\
\text { privatization improved access, expanded service, and } \\
\text { reduced child mortality. }\end{array}$} \\
\hline & China & Community Public Firm (Jin and Qian) & \\
\hline \multirow{3}{*}{ Financial Intermediation } & Mexico & Savings institution (Aportela) & \multirow{3}{*}{$\begin{array}{l}\text { Burgess and Pande exploit the introduction and } \\
\text { subsequent removal of a branch licensing program in } \\
\text { India which constrained branch openings in already } \\
\text { banked areas and increased branch opening in rural } \\
\text { unbanked areas to show that rural branch expansion } \\
\text { significantly lowered rural poverty, and increased non- } \\
\text { agricultural output. }\end{array}$} \\
\hline & India & $\begin{array}{l}\text { Rural bank branch expansion (Burgess and } \\
\text { Pande) } \\
\text { Change in eligibility for formal sector loan } \\
\text { (Banerjee and Duflo) } \\
\text { Financial development (Bell and Rousseau) } \\
\end{array}$ & \\
\hline & South Korea & Financial restraints (Demetriades and Luintel) & \\
\hline
\end{tabular}

Labor Market Institutions India ～Labor Regulation (Besley and Burgess)
Regulating labor market in a pro-worker direction lower investment, employment, productivity and output in registered manufacturing. Pro-worker amendments to the Industrial Disputes Act increase urban poverty.

\begin{tabular}{llll}
$\begin{array}{l}\text { Ethnolonguistic } \\
\text { Fractionalization }\end{array}$ & Kenya & $\begin{array}{l}\text { Ethnolinguistic Fractionalization (Miguel and } \\
\text { Gugerty) }\end{array}$ & $\begin{array}{l}\text { Variation in ethnic diversity across schools is used to } \\
\text { show that such diversity lowers primary school funding } \\
\text { and worsens school facilities. }\end{array}$ \\
\hline
\end{tabular}

Political representation and decentralization

Democratization India
(Foster and Rosenzweig, Bardhan and

Mookherjee, Pande, Chattopadhyay and Duflo,

Besley, Pande and Rao and Faguet)
Pande exploits quasi-random variation in mandated political representation for disadvantaged groups to show that it increased targeted redistribution towards these groups.
Ghana Kinship patterns (La Ferrara)

Trust
La Ferrara shows that about 67 percent of the total amount borrowed is borrowed from potential kinsmen, and suggests this is as membership in a dynastically linked community shapes individual incentives in economic transactions . 
Table-5: Impact of Land-titling and Registration Programs: Micro Evidence

\begin{tabular}{llcl}
\hline \hline Country (Paper) & Outcome & Data Set & Policy \\
Empirical strategies used in the papers are n the notes below. & & \\
\hline PANEL A: AFRICA
\end{tabular}

PANEL A: AFRICA

$\begin{array}{clll} & & \text { Year: Not given } & \\ \text { GHANA } & \text { i. Land Rights } & \text { Region: Wassa and } \\ \text { Besley(1995) } & \text { ii. Productivity } & \text { Anloga } \\ & & \text { Unit: } 334 \text { households } \\ & & \\ & & \\ \end{array}$

Year: 1987-1988

GHANA,

RWANDA AND

KENYA i. Credit Use

Migot-Adholla et ii. Inputs

al. (1991)

iii. Investment

iv. Yields

Place and Hazell

(1993)
Region: 10 rainfed

agriculture regions

None

Unit: Farm surveys
Having a deed has a significant positive effect on land rights that require approval in Wassa. In Anloga, the correlation is negative, suggesting lineage sanctions and title are substitutes. Land rights increase productivity.

No clear relationship between land registration and productivity (Migot-Adholla et al (1991)). Place and Hazell (1993) focus on land rights. Effects of land rights on credit are mixed; in one village, they increase moneylender borrowing; in another they decrease borrowing for food consumption. Land rights did not significantly affect input use. Strongest positive relationship between land rights and investment was for long-term investments in Rwanda; elsewhere mixed results. No significant relationship between land rights and yield.






\begin{tabular}{|c|c|c|c|c|}
\hline Country (Paper) & $\begin{array}{l}\text { Outcomes of } \\
\text { Interest }\end{array}$ & Data Set & Policy & Findings \\
\hline $\begin{array}{l}\text { UGANDA } \\
\text { Roth, Cochrane } \\
\text { and Kisamba- } \\
\text { Mugerwa (1994) }\end{array}$ & $\begin{array}{l}\text { i. Investment } \\
\text { ii. Perceived } \\
\text { Benefits }\end{array}$ & $\begin{array}{l}\text { Region: Kigezi District } \\
\text { Unit: } 228 \text { households } \\
\text { with } 505 \text { parcels }\end{array}$ & $\begin{array}{l}\text { Rujumbura Pilot Land } \\
\text { Registration Scheme } \\
\text { (1958) }\end{array}$ & $\begin{array}{l}\text { Households compelled to register their parcels receive less } \\
\text { cash income and remittances, and are significant coffee } \\
\text { producers. Those with voluntarily registered parcels own } \\
\text { more productive capital. Dispute incidence is lower for } \\
\text { registered land. Registration significantly increases farm } \\
\text { investments, with the effect more widespread for voluntary } \\
\text { (relative to compulsory) registration. }\end{array}$ \\
\hline
\end{tabular}

\section{PANEL B: ASIA}

INDIA

Banerjee, Gertler i. Productivity and Ghatak (2002)

\begin{tabular}{|c|c|c|c|}
\hline & & Year: 1993 & \\
\hline $\begin{array}{c}\text { INDIA } \\
\text { Pender and Kerr } \\
\text { (1999) }\end{array}$ & $\begin{array}{l}\text { i. Credit Use } \\
\text { ii. Investment } \\
\text { iii. Land Use }\end{array}$ & $\begin{array}{l}\text { Region: Aurepalle and } \\
\text { Dokur, Andhra Pradesh } \\
\text { Unit: Survey of } 291 \\
\text { households with } 563 \\
\text { plots. }\end{array}$ & $\begin{array}{l}\text { No specific policy; most } \\
\text { land is held in formal title, } \\
\text { "assigned" land has been } \\
\text { granted to poorer residents } \\
\text { who receive non- } \\
\text { transferable usufruct rights. }\end{array}$ \\
\hline
\end{tabular}

Year: 1983

THE PHILLIPINES

Friedman, Jimenez Land Value Region: Manila and Mayo (1993)

Year: 1979-1993

Region: West Bengal

Operation Barga (1977), which gave tenure security to registered sharecroppers

Relative to Bangladesh, the program raised sharecropper productivity in W.Bengal by $51 \%$. Fixed-effects estimate suggests the program boosted sharecropper productivity by $62 \%$.
Assigned land has a negative effect on supply and demand for moneylender and institutional credit. Adult males increase investment on assigned plots but decrease it on titled plots. Effect of household characteristics on investment is greater on titled plots. Share of land subject to sales restrictions has no effect on decision to cultivate in Aurepalle, and a negative effect in Dokur.
Unit: 1688 households

\begin{tabular}{|c|c|c|c|c|}
\hline $\begin{array}{c}\text { THAILAND } \\
\text { Feder and Onchan } \\
\text { (1987) }\end{array}$ & $\begin{array}{l}\text { i. Investment } \\
\text { ii. Credit Access }\end{array}$ & $\begin{array}{l}\text { Year: } 1987 \\
\text { Region: Lop-Buri, } \\
\text { Nakhon Ratchasima, and } \\
\text { Khon-Kaen Provinces } \\
\text { Unit: } 48 \text { compounds } \\
\end{array}$ & $\begin{array}{l}\text { Land Code (1954), which } \\
\text { created both title deeds and } \\
\text { utilization certificates for } \\
\text { private land. }\end{array}$ & $\begin{array}{l}\text { Titles increase capital accumulation, except in Lop-Buri, } \\
\text { where there is an ample non-institutional credit, more } \\
\text { commercialization, and lower-risk cash cropping. } \\
\text { Investment in bunding of land and clearing of stumps are } \\
\text { positively affected by land title, but effects are } \\
\text { insignificant in Lop-Buri. }\end{array}$ \\
\hline $\begin{array}{l}\text { THAILAND } \\
\text { Pagiola (1999) }\end{array}$ & $\begin{array}{l}\text { i. Program } \\
\text { Benefits } \\
\text { ii. Rate of Return } \\
\text { iii. Credit Access }\end{array}$ & $\begin{array}{l}\text { Year: 1991/92 and } \\
\text { 1995/96 } \\
\text { Region: National } \\
\text { Unit: Household survey }\end{array}$ & $\begin{array}{l}\text { Land Titling Project, Phase } \\
\text { 2, 1991-1994 }\end{array}$ & $\begin{array}{l}\text { Credit use increased faster in provinces where the program } \\
\text { was implemented. This increase was greatest in provinces } \\
\text { that were poorest at the outset. Results for productivity } \\
\text { were too sensitive to model specification to be useful. } \\
\text { Anecdotal information suggests titles increase land values. } \\
\text { The estimated rate of return from the program is } 34 \% \text {. }\end{array}$ \\
\hline $\begin{array}{c}\text { VIETNAM } \\
\text { Do and Iyer (2003) }\end{array}$ & $\begin{array}{l}\text { i. Investment } \\
\text { ii. Productivity } \\
\text { iii. Credit Access } \\
\text { iv. Land Transfers }\end{array}$ & $\begin{array}{l}\text { Year: 1992-1993 and } \\
1997-1998 \\
\text { Region: Not available. } \\
\text { Unit: panel of 4000+ } \\
\text { households. Province- } \\
\text { level data on LUC } \\
\text { issuance in 1994, } 1998 \\
\text { and 2000. }\end{array}$ & $\begin{array}{l}\text { Land Law (1993), which } \\
\text { allows for transferable } \\
\text { leases from the state } \\
\text { implemented using Land } \\
\text { Use Certificates (LUCs). }\end{array}$ & $\begin{array}{l}\text { Titled households increase proportion of multi-year crops } \\
\text { by } 7.5 \% \text { relative to untitled farms, at the expense of } \\
\text { annuals. Titled households increase irrigated area by } 20 \% \\
\text { and labor inputs by } 4.5 \text { weeks. Impact of title on credit } \\
\text { access is insignificant, but it does have a positive effect on } \\
\text { land transfers. }\end{array}$ \\
\hline
\end{tabular}




\begin{tabular}{|c|c|c|c|c|}
\hline Country (Paper) & $\begin{array}{l}\text { Outcomes of } \\
\text { Interest }\end{array}$ & Data Set & Policy & Findings \\
\hline
\end{tabular}

\begin{tabular}{|c|c|c|c|c|}
\hline $\begin{array}{c}\text { BRAZIL } \\
\text { Alston, Libecap, } \\
\text { and Mueller (2000) }\end{array}$ & i. Violent Conflict & $\begin{array}{l}\text { Year: 1991-1994 } \\
\text { (Conflict), } 1985 \text { (Census } \\
\text { Data) } \\
\text { Region: Para } \\
\text { Unit: } 105 \text { Municipos }\end{array}$ & $\begin{array}{l}\text { Formal Settlement } \\
\text { Programs organized by the } \\
\text { government agency } \\
\text { INCRA }\end{array}$ & $\begin{array}{l}\text { Squatting, forest clearing and large farms weaken property } \\
\text { rights, contributing to violent conflict. Value is } \\
\text { significantly related to conflict, and "higher land values } \\
\text { encourage invasions and evictions." }\end{array}$ \\
\hline $\begin{array}{l}\text { BRAZIL } \\
\text { Alston, Libecap, } \\
\text { and Schneider } \\
\text { (1996) }\end{array}$ & $\begin{array}{l}\text { i. Supply and } \\
\text { Demand for Title } \\
\text { ii. Land Value } \\
\text { iii. Investment }\end{array}$ & $\begin{array}{l}\text { Year: 1940-1970 (Para) } \\
\text { and 1870-1985 (Parana) } \\
\text { Region: Para and Parana } \\
\text { Unit: } 206 \text { households }\end{array}$ & $\begin{array}{l}\text { No specific policy; titling } \\
\text { is administered by state } \\
\text { governments. }\end{array}$ & $\begin{array}{l}\text { Title has a positive and significant effect on land value, } \\
\text { independent from its impact on investment, which } \\
\text { decreases with distance. The increase in land value } \\
\text { predicted by the value regressions has a positive but less } \\
\text { significant impact on title acquisition. Title increases } \\
\text { investment. }\end{array}$ \\
\hline
\end{tabular}

\begin{tabular}{|c|c|c|c|c|}
\hline \multirow[b]{2}{*}{$\begin{array}{c}\text { EQUADOR } \\
\text { Lanjouw and Levy } \\
\text { (2002) }\end{array}$} & \multirow[b]{2}{*}{$\begin{array}{l}\text { i. Land Value } \\
\text { ii. Perceptions of } \\
\text { Tenure Security } \\
\text { iii. Ability to } \\
\text { Transfer Land }\end{array}$} & \multicolumn{3}{|l|}{ Year: 1996} \\
\hline & & $\begin{array}{l}\text { Region: Guayaquil } \\
\text { Unit: } 400 \text { households } \\
\text { (1921 individuals) }\end{array}$ & $\begin{array}{l}1992 \text { Titling project } \\
\text { initiated by Municipality of } \\
\text { Guayaquil }\end{array}$ & $\begin{array}{l}\text { Title increases perceived market value of property by } \\
23.5 \% \text {. }\end{array}$ \\
\hline $\begin{array}{l}\text { GUATEMALA } \\
\text { Pagiola (1999) }\end{array}$ & $\begin{array}{l}\text { i. Program Rate o } \\
\text { Return }\end{array}$ & $\begin{array}{l}\text { Year: Not given } \\
\text { Region: Peten }\end{array}$ & $\begin{array}{l}\text { Land Administration } \\
\text { Project }\end{array}$ & $\begin{array}{l}\text { The estimated rate of return is } 12.3 \% \text {, and the profitability } \\
\text { of the program is robust to several changes in assumptions. }\end{array}$ \\
\hline $\begin{array}{l}\text { HONDURAS } \\
\text { Lopez (1996) }\end{array}$ & $\begin{array}{l}\text { i. Productivity } \\
\text { ii. Investment } \\
\text { iii. Access to } \\
\text { Credit }\end{array}$ & $\begin{array}{l}\text { Year: 1983-1994 } \\
\text { Region: Santa Barbara } \\
\text { and Comayogua } \\
\text { Unit: } 450 \text { farm } \\
\text { households }\end{array}$ & $\begin{array}{l}\text { Project funded by USAID, } \\
\text { initiated in } 1983 .\end{array}$ & $\begin{array}{l}\text { Average investment for USAID-funded farmers was twice } \\
\text { that of others. A greater proportion of these farmers } \\
\text { received credit, and in larger amounts. The difference in } \\
\text { yields between the two groups was statistically significant } \\
\text { in } 1993 \text { but not } 1983 \text {. Rate of return to the titling project } \\
\text { was } 17 \% \text {. }\end{array}$ \\
\hline $\begin{array}{c}\text { NICARAGUA } \\
\text { Deninger and } \\
\text { Chamorro (2003) }\end{array}$ & $\begin{array}{l}\text { i. Investment } \\
\text { ii. Land Value }\end{array}$ & $\begin{array}{l}\text { Region: National } \\
\text { Unit: } 2476 \text { households } \\
\text { (3212 plots) }\end{array}$ & $\begin{array}{l}\text { Programa Nacional de } \\
\text { Catastro, Titulacion y } \\
\text { Registro, since 1992, } \\
\text { which encourages titling } \\
\text { and registration. }\end{array}$ & $\begin{array}{l}\text { Full registration increases investment; title without } \\
\text { registration has only an insignificant impact. Registration } \\
\text { affects plot-level, not household-level, investment, } \\
\text { suggesting access to credit is unaffected. Registration } \\
\text { increases land values by } 30 \% \text { (same effect as } 20 \text { years of } \\
\text { continuous possession). }\end{array}$ \\
\hline
\end{tabular}

\begin{tabular}{|c|c|c|c|c|}
\hline & i. Land & Year: Not given & & \\
\hline $\begin{array}{l}\text { NICARAGUA } \\
\text { Broegaard et al. } \\
\text { (2002) }\end{array}$ & $\begin{array}{l}\text { Registration } \\
\text { ii. Perceived } \\
\text { Tenure Insecurity } \\
\text { iii. Land Use } \\
\text { iv. Land Values } \\
\text { v. Credit Access } \\
\text { vi. Agricultural } \\
\text { Production }\end{array}$ & $\begin{array}{l}\text { Unit: } 921 \text { households } \\
\text { with } 975 \text { plots of land }\end{array}$ & $\begin{array}{l}1997 \text { legislation } \\
\text { sanctioning ownership by } \\
\text { beneficiaries of Sandinista } \\
\text { redistribution }\end{array}$ & $\begin{array}{l}\text { Complete formal documents improve tenure security. } \\
\text { Formal title deeds increase probability of public } \\
\text { registration and permanent crop cultivation, and reduce } \\
\text { perceived future tenure conflict. Formal title has a small } \\
\text { positive effect on land value and none on credit. Land- } \\
\text { reform documents increase registration and tenure security, } \\
\text { but effects are smaller than the impacts of formal title. } \\
\text { Further, they do not affect permanent crop cultivation. }\end{array}$ \\
\hline
\end{tabular}

\begin{tabular}{|c|c|c|c|c|}
\hline $\begin{array}{l}\text { NICARAGUA de } \\
\text { Laiglasia (2004) }\end{array}$ & $\begin{array}{l}\text { i. Investment } \\
\text { ii. Determinants } \\
\text { of Registration } \\
\text { iii. Credit Access }\end{array}$ & $\begin{array}{l}\text { Year: } 1996 \text { and } 1999 \\
\text { Region: National } \\
\text { Unit: } 2476 \text { households } \\
\text { (3212 plots) }\end{array}$ & $\begin{array}{l}\text { Programa Nacional de } \\
\text { Catastro, Titulacion y } \\
\text { Registro, since 1992, } \\
\text { which encourages titling } \\
\text { and registration. }\end{array}$ & $\begin{array}{l}\text { Land registration increases the probability of land-attached } \\
\text { investment by } 35 \% \text {-- the specific type of title (excluding } \\
\text { indigenous forms) is unimportant. No link between credit } \\
\text { and land registration. }\end{array}$ \\
\hline $\begin{array}{l}\text { PARAGUAY } \\
\text { Carter and Olinto } \\
\quad(2000)\end{array}$ & $\begin{array}{l}\text { i. Investment } \\
\text { ii. Credit Access }\end{array}$ & $\begin{array}{l}\text { Year: } 1987 \\
\text { Region: Paraguari, San } \\
\text { Pedro and Itapua } \\
\text { Unit: } 48 \text { compounds } \\
\text { holding } 351 \text { parcels }\end{array}$ & $\begin{array}{l}\text { No General Progam: Land } \\
\text { can be either "Titled" or } \\
\text { "Formal" but untitled. }\end{array}$ & $\begin{array}{l}\text { Legal security improves attached capital and has } \\
\text { negative impact on movable capital. Positive impact of title } \\
\text { on investment weaker for liquidity-constrained farms, and } \\
\text { reductions in movable capital are not offset by increases in } \\
\text { attached capital for small farms. Below } 3 \text { hectares no effect } \\
\text { on credit rationing probability. }\end{array}$ \\
\hline
\end{tabular}

\section{PERU}

Antle, Yanggen,

Valdivia, and

Crissman (2003)
Year: 1997-1999

Region: Cajamarca

Unit: 847 parcels
Proyecto Especial de Titulacion des Tierras (Special Land Titling Project), encourages farmers to obtain titles.
Accounting for endogenous titling, titling increases the mean probability of terracing from $25.8 \%$ to $32.4 \%$. 


\begin{tabular}{|c|c|c|c|c|}
\hline Country (Paper) & $\begin{array}{l}\text { Outcomes of } \\
\text { Interest }\end{array}$ & Data Set & Policy & Findings \\
\hline $\begin{array}{c}\text { PERU } \\
\text { Field (2003) } \\
\text { Field and Torero } \\
\text { (2004) }\end{array}$ & $\begin{array}{l}\text { i. Labor Supply } \\
\text { (Field) } \\
\text { ii. Credit Access } \\
\text { (Field and Torero) }\end{array}$ & $\begin{array}{l}\text { Year: March } 2000 \\
\text { (middle of the program) } \\
\text { Region:Urban } \\
\text { Unit: } 2750 \text { households }\end{array}$ & $\begin{array}{l}\text { i. Committee for the } \\
\text { Formalization of Private } \\
\text { Property } \\
\text { ii. Decree 424: Law for } \\
\text { Formalization of Informal } \\
\text { Properties (1996): From } \\
1992 \text { to } 1997 \text { over } 1.2 \\
\text { million urban households } \\
\text { given formal property } \\
\text { titles. }\end{array}$ & $\begin{array}{l}\text { Untitled households work } 17 \% \text { less hours than those with } \\
\text { titles and are } 47 \% \text { more likely to work inside the home. } \\
\text { Titled households are } 28 \% \text { less likely to engage in child } \\
\text { labor (Field). Untitled households are } 10 \% \text { less likely to be } \\
\text { approved for formal sector loans. Titling does not affect } \\
\text { private sector approval rates, but lowers the interest rate by } \\
9 \% \text { (Field and Torrero). }\end{array}$ \\
\hline
\end{tabular}

Notes on empirical strategies used in above papers:

Conflict incidence estimated as a function of settlements, squatting, forest clearing, farm size, value, and number of establishments. Alston, Libecap, and Instrument for settlements are federal versus provincial jurisdiction, distance from state capital, and area of projects receiving Mueller (2000) institutional credit.

Alston, Libecap, and Census ans survey data for land value and investment, survey data for determinants of land titling, land value and investment. Schneider (1996) Expected change in value and landholder characteristics are used as instruments for title.

Antle, Yanggen,

Valdivia, and

Crissman (2003)

Impact on terracing on title with farm size and years of ownership as instruments for obtaining land title.

Banerjee, Gertler and Difference-in-differences comparisons of yield per acre using district panel data with West Bengal as treatment and Bangladesh as a Ghatak (2002) control group. Exploit over time variation in sharecropper registration rates in West Bengal for fixed effects model.

\begin{tabular}{ll}
\hline Besley (1995) & Effect of transfer rights on productivity using title deed as instrument for transfer rights. \\
$\begin{array}{l}\text { Broegaard et al, } \\
(2002)\end{array}$ & Titles are instrumented using wealth and education. \\
\hline
\end{tabular}

Carter and Olinto Simulated maximum likelihood to separate liquidity constrainted and unconstrained households. Impact of title status on attached (2000) and unattached capital estimated using OLS first-differences.

Cartier, Wiebe and Compare farms with and without titles. Plot level regression with farm fixed effects for 26 farms with plots under a variety of Blarel (1994) arrangements. \begin{tabular}{ll}
\hline Investment from 1996 to 1999 as a function of tenure status. Household fixed effects are used to deal with unobserved heterogenity, \\
and endogeneity is controlled for by repeating the regression only for households participating in legalization and by instrumenting \\
registration with documents held.
\end{tabular}

Deninger and Probit for the effect of title on investment occuring and tobit for the amount of investment. The impact on land values uses Chamorro (2003) household fixed effects.

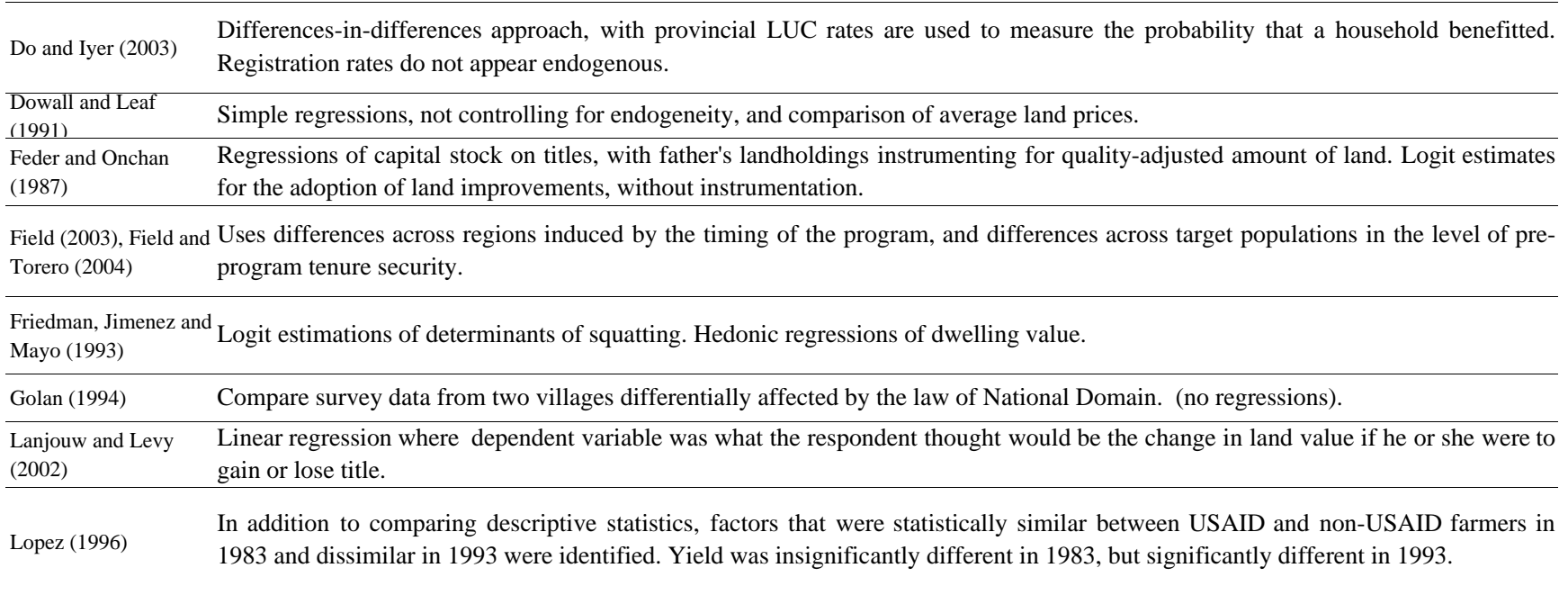


Notes on empirical strategies used in above papers:

Migot-Adholla et al Details are not available (table information is based on a description in Feder and Nishio (1998)).

(1991)

Migot-Adholla, Place

and Oluoch-Kosura

Estimate effect of title on (i) fourteen types of farm investment (ii) yield

(1994)

Pagiola (1999)

For Thailand, he takes results from other studies about the benefits of land titling in Thailand before producing a cost-benefit analysis, while for Guatemala he uses observed willingness to pay to measure benefits.

Pender and Kerr

Maximum likelihood switching regressions are used to separate the effects of title on credit demand and supply. Because of the

(1993) simultaneous occurance of land use and investment, and possible dependence on previous investment a "simultaneous tobit-probit" model was created for this paper.

Pinckney and Kimuyu

(1994)

Comparison of two samples (no regressions).

Place and Hazell (1993)

Household fixed effects are used to deal with unobservables, but no instruments are available to tackle endogeneity.

Place and Migot-

Comparison of descriptive statistics. Predicted title is used as an explanatory variable in the credit and investment equations; due to Adholla (1998) lack of variation in predicted title, error-components GLS was used.

Roth, Cochrane and

Kisamba-Mugerwa

Estimate effect of registration on six types of investment.

(1994)

Roth, Unruh, and

Barrows (1994)

Regressions with land value and investment demand as outcomes. Do not account for endogenous registeration. 
Table-6: Perceptions of Land Rights

Percent of Cultivated Plots on which Respondent Claims Right to:

$\begin{array}{lll}\text { Determine } & \text { Rent Out } & \text { Lend Out }\end{array}$

Inheritance

(1)

(2)

(3)

(4)

Non-office holders

6

22

32

15

Office holders

26

53

60

32

t-test for equality

6.41

6.74

5.83

4.34

Number of observations

575

576

576

575

Notes: 
Table-7: Fallow Duration, Profits, and Political Office

\begin{tabular}{|c|c|c|c|c|}
\hline & $\begin{array}{c}\text { Fallow } \\
\text { Duration } \\
\text { (Years) } \\
\end{array}$ & $\begin{array}{l}\text { Plot Profit } \\
\text { (1000 cedis) } \\
\end{array}$ & $\begin{array}{c}\text { Fallow } \\
\text { Duration } \\
\text { (Years) } \\
\end{array}$ & $\begin{array}{c}\text { Fallow } \\
\text { Duration } \\
\text { (Years) } \\
\end{array}$ \\
\hline & OLS & IV & OLS & $\begin{array}{c}\text { Individual } \\
\text { F.E. }\end{array}$ \\
\hline & (1) & (2) & (3) & (4) \\
\hline Fallow duration & & $\begin{array}{c}314 \\
(182)\end{array}$ & & \\
\hline Female & $\begin{array}{l}-0.430 \\
(0.54)\end{array}$ & $\begin{array}{c}143 \\
(426)\end{array}$ & $\begin{array}{l}-0.921 \\
(0.36)\end{array}$ & \\
\hline 1 if resp. holds trad. office & $\begin{array}{l}1.950 \\
(0.80)\end{array}$ & & $\begin{array}{l}3.085 \\
(0.64)\end{array}$ & \\
\hline Commercially-obtained plot & & & $\begin{array}{l}0.633 \\
(0.34)\end{array}$ & $\begin{array}{l}0.698 \\
(0.24)\end{array}$ \\
\hline Office*Commercially-obtained & & & $\begin{array}{l}-0.407 \\
(0.78)\end{array}$ & \\
\hline 1 if first of family in town & $\begin{array}{l}0.290 \\
(0.64)\end{array}$ & & & \\
\hline Years family/resp lived in village & $\begin{array}{l}0.010 \\
(0.01)\end{array}$ & & & \\
\hline Number of wives of father & $\begin{array}{l}0.520 \\
(0.23)\end{array}$ & & & \\
\hline Number of father's children & $\begin{array}{l}-0.020 \\
(0.05)\end{array}$ & & & \\
\hline Parity of mother in father's wives & $\begin{array}{l}-0.420 \\
(0.36)\end{array}$ & & & \\
\hline 1 if fostered as child & $\begin{array}{l}0.350 \\
(0.61)\end{array}$ & & & \\
\hline Size of inherited land & $\begin{array}{l}-0.520 \\
(0.57)\end{array}$ & & & \\
\hline 1 if mother had any education & $\begin{array}{l}0.960 \\
(1.05)\end{array}$ & & & \\
\hline 1 if father had any education & $\begin{array}{l}-0.980 \\
(0.63)\end{array}$ & & & \\
\hline \multicolumn{5}{|c|}{$\begin{array}{l}\text { Notes: All regressions include plot controls (deciles of area, indicators of soil type, } \\
\text { toposequence, and location), full set of plot characteristics, full set of family } \\
\text { background variables, household and spatial fixed effects. All regressions also include } \\
\text { spatial fixed effects, with radius of } 250 \text { meters. Standard errors,corrected for spatial } \\
\text { correlations as in Conley (1999), are given in parentheses. }\end{array}$} \\
\hline
\end{tabular}


Table-8: Fallowing, Networks and Abusua Resources

\begin{tabular}{|c|c|c|c|}
\hline & $\begin{array}{c}(1) \\
\text { Last Fallow Duration } \\
\text { Parameter Estimate }\end{array}$ & $\begin{array}{c}(2) \\
\text { Last Fallow Duration } \\
\text { Parameter Estimate }\end{array}$ & $\begin{array}{c}\text { (3) } \\
\text { Last Fallow Duration } \\
\text { Parameter Estimate }\end{array}$ \\
\hline$\overline{\text { Female }}$ & $\begin{array}{c}0.12 \\
(0.45)\end{array}$ & $\begin{array}{c}-0.66 \\
(0.35)\end{array}$ & $\begin{array}{c}-0.69 \\
(0.60)\end{array}$ \\
\hline Office & $\begin{array}{c}2.67 \\
(0.45)\end{array}$ & $\begin{array}{c}3.88 \\
(0.63)\end{array}$ & $\begin{array}{c}-2.44 \\
(2.21)\end{array}$ \\
\hline Talk Frequently w/Office Holder & $\begin{array}{c}2.05 \\
(0.53)\end{array}$ & & \\
\hline Households in Abusua/ha & & $\begin{array}{c}-0.23 \\
(0.05)\end{array}$ & $\begin{array}{c}-0.63 \\
(0.58)\end{array}$ \\
\hline Office*Households in Abusua/ha & & & $\begin{array}{c}3.38 \\
(1.37)\end{array}$ \\
\hline Number of observations & 323 & 368 & 368 \\
\hline Quintiles of Population Density & $25 \%$ & $50 \%$ & $75 \%$ \\
\hline Households in Abusua/ha & 1.08 & 1.91 & 2.60 \\
\hline
\end{tabular}


Table-9: Abusua Land and Leadership Characteristics

\begin{tabular}{|c|c|c|c|c|c|c|}
\hline & $\begin{array}{l}\text { Assets } \\
\text { (Thousand } \\
\text { Cedis) } \\
\text { (1) } \\
\end{array}$ & $\begin{array}{c}\text { Area } \\
\text { Cultivated } \\
\text { (Hectares) } \\
(2) \\
\end{array}$ & $\begin{array}{c}\text { Household } \\
\text { Size } \\
\text { (3) } \\
\end{array}$ & $\begin{array}{l}\text { Number of } \\
\text { Adults } \\
\text { (4) }\end{array}$ & $\begin{array}{c}\text { Went to } \\
\text { School } \\
\text { (1=yes) } \\
(5) \\
\end{array}$ & $\begin{array}{c}\text { PCE } \\
\text { (Thousand } \\
\text { Cedis) } \\
\text { (6) }\end{array}$ \\
\hline \multicolumn{7}{|c|}{ PANEL A: Sample of Office Holders } \\
\hline Abusua land per Household & $\begin{array}{c}405 \\
(1163)\end{array}$ & $\begin{array}{c}4.703 \\
(1.197)\end{array}$ & $\begin{array}{c}2.992 \\
(0.516)\end{array}$ & $\begin{array}{c}2.134 \\
(0.413)\end{array}$ & $\begin{array}{c}0.350 \\
(0.175)\end{array}$ & $\begin{array}{c}9 \\
(42)\end{array}$ \\
\hline Number of observations & 50 & 32 & 43 & 43 & 43 & 36 \\
\hline \multicolumn{7}{|c|}{ PANEL B: Sample of All Cultivators } \\
\hline Office & $\begin{array}{c}582 \\
(939)\end{array}$ & $\begin{array}{l}-1.468 \\
(0.866)\end{array}$ & $\begin{array}{c}0.546 \\
(0.589)\end{array}$ & $\begin{array}{l}-0.184 \\
(0.665)\end{array}$ & $\begin{array}{l}-0.410 \\
(0.119)\end{array}$ & $\begin{array}{l}-53 \\
(37)\end{array}$ \\
\hline Abusua land per household & $\begin{array}{c}137 \\
(197)\end{array}$ & $\begin{array}{c}0.957 \\
(0.416)\end{array}$ & $\begin{array}{c}1.715 \\
(0.976)\end{array}$ & $\begin{array}{c}0.336 \\
(0.448)\end{array}$ & $\begin{array}{l}-0.272 \\
(0.092)\end{array}$ & $\begin{array}{l}-56 \\
(20)\end{array}$ \\
\hline $\begin{array}{l}\text { Office * Abusua land per } \\
\text { household }\end{array}$ & $\begin{array}{c}268 \\
(1165)\end{array}$ & $\begin{array}{c}3.745 \\
(1.375)\end{array}$ & $\begin{array}{c}0.875 \\
(1.008)\end{array}$ & $\begin{array}{c}1.899 \\
(0.803)\end{array}$ & $\begin{array}{c}0.622 \\
(0.156)\end{array}$ & $\begin{array}{c}80 \\
(42)\end{array}$ \\
\hline Number of observations & $\begin{array}{c}325 \\
\text { individuals }\end{array}$ & $\begin{array}{c}191 \\
\text { cultivators }\end{array}$ & $\begin{array}{c}153 \\
\text { households }\end{array}$ & $\begin{array}{c}153 \\
\text { households }\end{array}$ & $\begin{array}{c}303 \\
\text { individuals }\end{array}$ & $\begin{array}{c}274 \\
\text { households }\end{array}$ \\
\hline
\end{tabular}




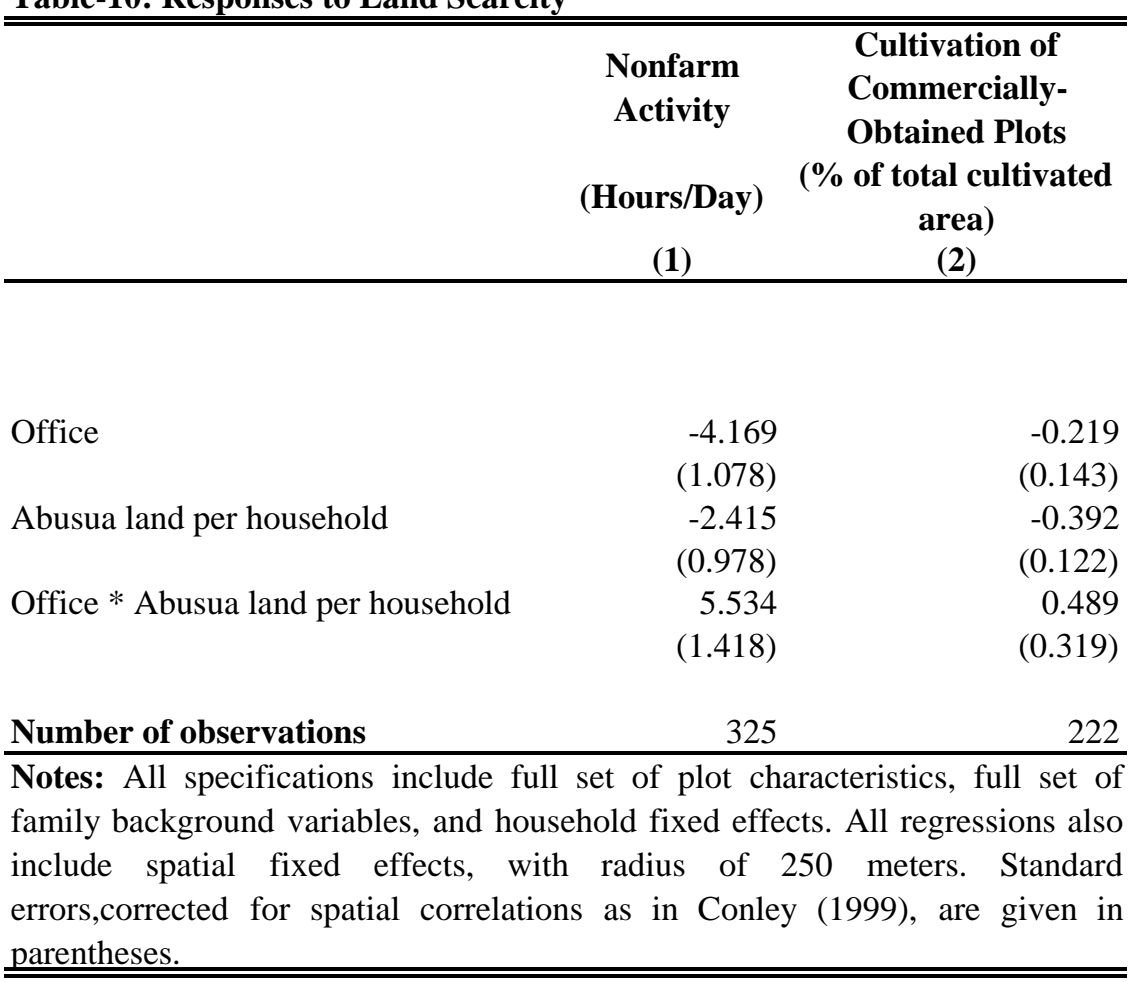

